\title{
Physiological and Molecular Response of Wheat Cultivars to Titanium Dioxide or Zinc Oxide Nanoparticles under Water Stress Conditions
}

\author{
Hala Mohamed Safwat El-Bassiouny, ${ }^{1}$ Heba Amin Mahfouze, ${ }^{2}$ \\ Maha Mohamed Shater Abdallah (D), ${ }^{1}$ Bakry Ahmed Bakry, ${ }^{3}$ \\ and Magda Aly Mahmoud El-Enany ${ }^{2}$ \\ ${ }^{1}$ Botany Department, Agricultural and Biological Research Institute, National Research Centre, \\ 33 El Bohouth Street P.O. 12622. Dokki, Giza, Egypt \\ ${ }^{2}$ Department of Cytology and Genetics, Biotechnology Research Institute, National Research Centre, \\ 33 El Bohouth Street P.O. 12622. Dokki, Giza, Egypt \\ ${ }^{3}$ Field Crops Research Department, Agricultural and Biological Research Institute, National Research Centre, \\ 33 El Bohouth Street P.O. 12622. Dokki, Giza, Egypt \\ Correspondence should be addressed to Maha Mohamed Shater Abdallah; maha_eg1908@yahoo.fr
}

Received 8 October 2021; Accepted 7 January 2022; Published 2 February 2022

Academic Editor: Allen Barker

Copyright (C) 2022 Hala Mohamed Safwat El-Bassiouny et al. This is an open access article distributed under the Creative Commons Attribution License, which permits unrestricted use, distribution, and reproduction in any medium, provided the original work is properly cited.

\begin{abstract}
A field trial was conducted through two successive winter seasons 2017/2018 and 2018/2019 to evaluate the influence of $\mathrm{TiO}_{2}$ or $\mathrm{ZnO}$ nanoparticles on two wheat cultivars (Gimeza 12 and Sids 13) under different water irrigation requirements of $100 \%$ (WW) and $75 \%$ (WS). The results showed that drought stress decreases morphological parameters, photosynthetic pigments, and wheat yield $\left(\mathrm{ha}^{-1}\right)$. However, the total soluble sugars, total free amino acids, proline content, and water productivity were increased. Application of $\mathrm{TiO}_{2}$ or $\mathrm{ZnO}$ nanoparticles declines the negative influence of water deficit. Furthermore, SDS-PAGE revealed in Gimeza 12 treated with $\mathrm{TiO}_{2}$ or $\mathrm{ZnO}$ nanoparticles, it stimulates the appearance of some proteins at the MW of $28 \mathrm{kDa}$ in WW and WS, while in WS, it records the new polypeptide at $18 \mathrm{kDa}$. Moreover, Gimeza 12 treated with nano- $\mathrm{TiO}_{2}$ led to the disappearance of two bands at 163 and $51 \mathrm{kDa}$ in WS. However, for Sids13, there was no difference between the treatments in WW and WS except in nano- $\mathrm{ZnO}$ at WS that disappeared the polypeptides at MWs of 163, 51, and $18 \mathrm{kDa}$. Primer SRAP results showed that the plants treated with $\mathrm{TiO}_{2}$ or $\mathrm{ZnO}$ nanoparticles had a minor effect at the genomic DNA level, which was illustrated by the appearance or absence of some bands. Besides, the low concentrations of nanoparticles did not damage DNA. On the other hand, one negative marker of -233 bp disappeared in the Gimeza 12 cultivar treated with WS + nano- $\mathrm{TiO}_{2}$ and was revealed in the other treatments using primer SRAP-2. The results showed that the Gimeza 12 cultivar which had the highest grain yield was more tolerant to drought than the Sids 13 cultivar.
\end{abstract}

\section{Introduction}

Water stress is regularly associated with main abiotic stresses such as heat stress and salt stress; thus, this is deliberated as one of the elementary agents accountable for crop yield decrease [1]. So, water preservation is becoming a critical deliberation for agriculture. Water stress produced an opposing influence on plants through decreased growth, nutrient achievement reduction, and water status of plants [2]. During photosynthesis, water stress induced a reduction of photosynthetic efficiency because of the increased accumulation of reactive oxygen species [3]. Thus, plants use various mechanisms to increase overall growth performance for sustaining the yield quality under changeable environmental stresses [4]. Plants enhance the osmoprotectants production (such as total soluble sugar and proline) and 
antioxidant enzymes, which enables plants to overcome water stress [5].

Nanoparticles (NPs) are minute particles of less than $1000 \mathrm{~nm}$. These particles are very gorgeous compounds to utilize in a biological system. NPs respond with plants producing various morphological and physiological alterations based on the nanoparticles' characteristics. In this regard, Ma et al. [6] showed that the stimulation and reduction have an impact on plant growth and development, based on the size, structure, concentration, and physical and chemical properties of nanoparticles in addition to plant species. Nanotechnology is one of the options that increase the nutritional values of crops, so some engineered nanoparticles (NPs) could be used as a fertilizer.

Titanium has important biological influences on plants. It is useful at lower concentrations but has cytotoxicity and genotoxicity at higher concentrations [7]. Ti-NPs raise the plant's tolerance against environmental stresses and reduce free radicals. It converts $\mathrm{O}_{2}$ free radicals to $\mathrm{O}_{2}$ also, alters from $\mathrm{Ti}^{4+}$ to $\mathrm{Ti}^{+3}$, and so as to keep its form, it alters $\mathrm{O}_{2}$ to $\mathrm{H}_{2} \mathrm{O}_{2}$ and then changes to $\mathrm{Ti}^{4+}$ [8]. Nano- $\mathrm{TiO}_{2}$ improved spinach seed germination and plant growth [9]. The nano$\mathrm{TiO}_{2}$ raises the activity of the plant via raising the initial photosystem light energy. This is absorbed through the chloroplast membrane and moved to the photosystem II [10]. $\mathrm{TiO}_{2}-\mathrm{NPs}$ can readily catalyze oxidation and regeneration reactions and increase the rate of liberation of whole energy electrons because of the size of the particles is very small [11]. Meanwhile, $\mathrm{TiO}_{2}$ enhances plants' division and size, so it is recommended as a growth regulator [12].

Zinc oxide nanoparticles (nano- $\mathrm{ZnO}$ ) play an enormous pivotal function in plants and are generally used in agricultural applications [13]. ZnO-NPs activated the embryogenesis of somatic cells, regenerating plantlets, growth, and progressed tolerance to abiotic stress via improving the synthesis of proline and antioxidant enzymes [14]. ZnO-NPs nanoparticles increased seed germination, plant growth, and development of several plant species [15]. In this connection, Singh et al. [16] showed the beneficial influence of $\mathrm{ZnO}-\mathrm{NPs}$ at low concentrations in mung bean and tomato, respectively. Zinc as a catalyzer has an activating or building role in many enzymes in plants [17]. Moreover, alteration of endogenous phytohormone levels was induced by nanoparticles which increased stress tolerance [18]. Also, Abdel Latef et al. [19] detected that ZnNPs treatment enhanced growth of lupine plants under salinity stress which regulates hormonal metabolism through modification of tryptophan biosynthesis, thus activating cell division and enlargement.

DNA fingerprinting is a beneficial biomarker examination in the evaluation of the mutagenicity of chemicals and trace metals on plants [20]. Molecular markers like sequence-related amplified polymorphism (SRAP) have been usefully used to reveal alterations in DNA fingerprints that reverberate DNA differences in the genome [21].

Cereal crops such as wheat are one of the most important plants due to their natural genetic variation [22]. It is considered the most important food grain due to its covering approximately $21 \%$ of the world's food supply and is an essential source of protein in developing countries [23].
So, the target of our work was to research the effect of nano- $\mathrm{TiO}_{2}$ or nano- $\mathrm{ZnO}$ in mitigating the impact of water stress on growth, yield, some biochemical aspects, and molecular change of two wheat (Gimeza 12 and Sids 13) cultivars.

\section{Materials and Methods}

2.1. Materials. Grains of the wheat cultivars (Gimeza 12 and Sids 13) were supplied by the Agricultural Research Centre in Egypt. Titanium dioxide and zinc oxide nanoparticles (NPs) were bought from Sigma-Aldrich Company.

2.2. Experiment Location. Two field experiments were carried out in two successive winter seasons of 2017/2018 and 2018/2019 at the Experimental Farm of National Research Centre Nubaria region, Egypt (30_86'67" N 31_16'67" E), with the mean altitude being $21 \mathrm{~m}$ above sea level. The farm is classified as an arid or semiarid region. The daytime temperature ranged from 17.61 to $32.4^{\circ} \mathrm{C}$ with an average of $24.38^{\circ} \mathrm{C}$ and 18.82 to $28.15^{\circ} \mathrm{C}$ with an average of $22.52^{\circ} \mathrm{C}$, whereas the temperature at night was 6.4 to $16.82^{\circ} \mathrm{C}$ with an average of 10.7 and 8.7 to $16.23^{\circ} \mathrm{C}$ with an average of $11.8^{\circ} \mathrm{C}$. The relative humidity was in ranges from 39.1 to 62.22 with an average of $54.1 \%$ and 58.0 to $69.38 \%$ with an average of $64.4 \%$ in $2017 / 2018$ and 2018/2019, respectively. Figure 1 shows the climatic data of the experimental site through the two growing seasons. Total precipitation through both successive winter seasons for wheat to be subtracted from the total amount of water calculated $68.1 \mathrm{~mm}=680 \mathrm{~m}^{3} / \mathrm{ha}$ and $61.7 \mathrm{~mm}=617 \mathrm{~m}^{3} / \mathrm{ha}$ in $2017 / 2018$ and $2018 / 2019$, respectively.

The sandy soil of the experimental site was conducted at the Experimental Station of the National Research Centre, Al-Nubaria district, El-Beheira governorate, Egypt. Physical and chemical analysis of the sandy soil of the experimental site (Table 1) is determined according to Chapman and Pratt [24]. These results were previously mentioned by Bakry et al. [25] in the same region.

2.3. Experiment Design. The wheat grains were washed with distilled water, sterilized with $1 \%$ sodium hypochlorite solution for about 2 minutes, and washed again with distilled water. The grains were soaked in different rates of nano- $\mathrm{TiO}_{2}$ or nano-ZnO $(5 \mathrm{mg} / \mathrm{L}$ and $10 \mathrm{mg} / \mathrm{L})$ for 12 hours before sowing. The experiment was designed in a split-split plot design with four replicates, where the water irrigation requirements (WIR) were 100\% (WW) and 75\% (WS) occupied the main plots, whereas both wheat cultivars (Gimeza-12 and Sids-13) were randomly assigned in subplots. Meanwhile, the treatments of nano- $\mathrm{TiO}_{2}$ or nano- $\mathrm{ZnO}$ were randomly assigned in sub-sub plots. On $26^{\text {th }}$ November, the grains of wheat were cultivated in two seasons in rows $3.5 \mathrm{~m}$ long, and the distance between rows was $20 \mathrm{~cm}$ apart. The plot area was $10.5 \mathrm{~m}^{2}$ (3.0 $\mathrm{m}$ in width and $3.5 \mathrm{~m}$ in length).

The agricultural practices were carried out as recommended of sowing wheat under sandy soil conditions, and the seeding rate was $140 \mathrm{~kg} \mathrm{ha}^{-1}$. Presowing, $360 \mathrm{~kg} \mathrm{ha}^{-1}$ of 


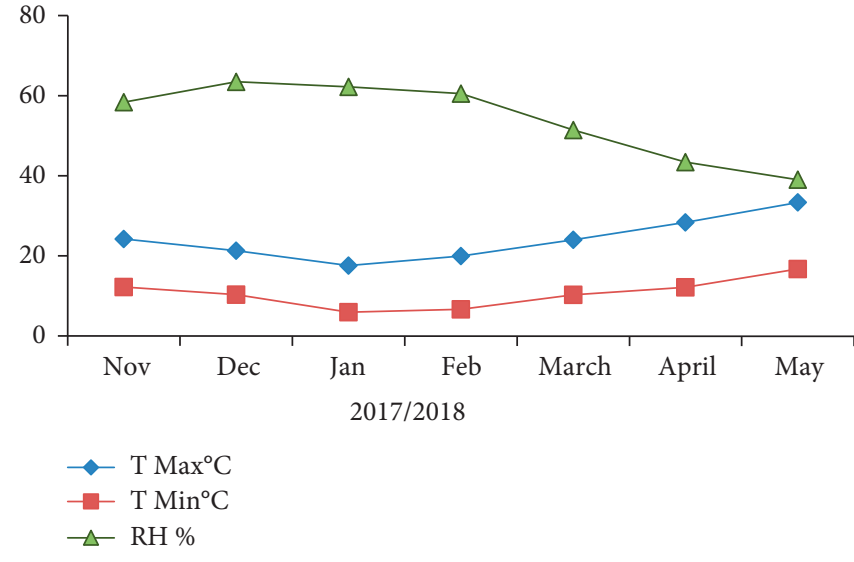

(a)

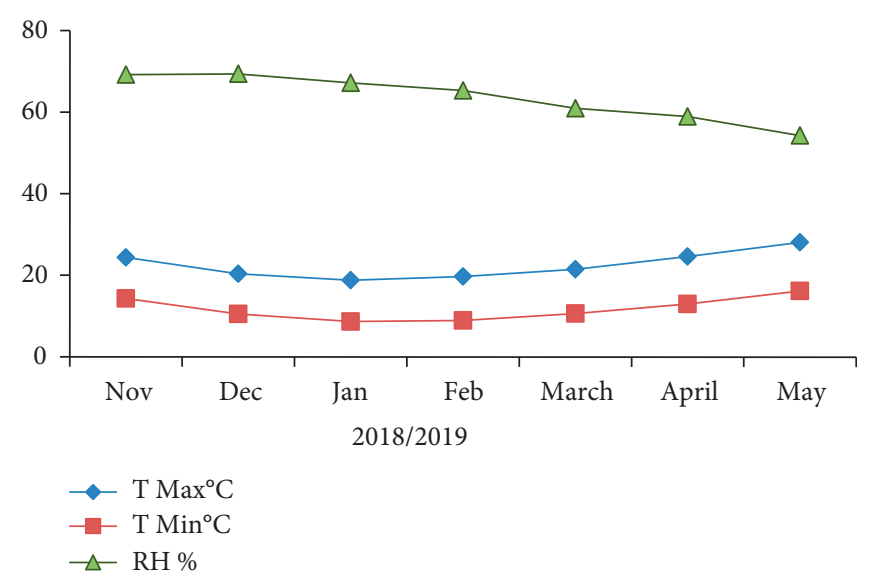

(b)

FIGURE 1: The data of maximum temperature $\left(\operatorname{TMax}^{\circ} \mathrm{C}\right)$, minimum temperature ( $\left.\mathrm{TMin}^{\circ} \mathrm{C}\right)$, and average relative humidity $(\mathrm{RH} \%)$, obtained from the weather station installed at the experimental station of the National Research Centre, Nubaria, shows the climatic data of the experimental site during the growing season.

TAвLE 1: Physical, chemical, and nutritional analysis of the experimental soil.

\begin{tabular}{|c|c|c|c|c|c|c|c|c|c|c|c|c|c|c|}
\hline Season & \multicolumn{3}{|c|}{ Constant depth $(\mathrm{cm})$} & \multicolumn{2}{|c|}{ Coarse sand (\%) } & \multicolumn{3}{|c|}{ Fine sand (\%) } & \multicolumn{3}{|c|}{ Silt (\%) } & \multicolumn{2}{|c|}{ Clay (\%) } & $\begin{array}{l}\text { Texture } \\
\text { class }\end{array}$ \\
\hline $2017 /$ & \multicolumn{3}{|c|}{$00-30$} & \multicolumn{2}{|c|}{40.7} & \multicolumn{3}{|c|}{44.6} & \multicolumn{3}{|c|}{10.7} & \multicolumn{2}{|r|}{4} & Sandy \\
\hline 2018 & \multicolumn{3}{|c|}{$30-60$} & 38.2 & & \multicolumn{3}{|c|}{43} & \multicolumn{3}{|c|}{13.8} & \multicolumn{2}{|r|}{5} & Sandy \\
\hline $2018 /$ & \multicolumn{3}{|c|}{$00-30$} & 38.7 & & \multicolumn{3}{|c|}{42.6} & \multicolumn{3}{|c|}{13.7} & \multicolumn{2}{|c|}{5} & Sandy \\
\hline 2019 & \multicolumn{3}{|c|}{$30-60$} & 36.5 & & \multicolumn{3}{|c|}{38.1} & \multicolumn{3}{|c|}{17.8} & \multicolumn{2}{|c|}{7.6} & Sandy \\
\hline \multirow{2}{*}{ Season } & \multirow{2}{*}{$\begin{array}{l}\text { Constant } \\
\text { depth }(\mathrm{cm})\end{array}$} & \multirow[t]{2}{*}{$\mathrm{pH}$} & \multirow{2}{*}{$\begin{array}{c}\text { Electrical } \\
\text { conductivity } \\
(\mathrm{dS} / \mathrm{m})\end{array}$} & \multirow{2}{*}{$\begin{array}{c}\text { Coarse } \\
\text { sand }(\%)\end{array}$} & \multicolumn{4}{|c|}{$\begin{array}{c}\text { Anions } \\
\text { (milliequivalents/liter) }\end{array}$} & \multicolumn{4}{|c|}{$\begin{array}{c}\text { Cations } \\
\text { (milliequivalents/liter) }\end{array}$} & \multirow{2}{*}{$\begin{array}{c}\mathrm{CaCo} \\
(\%)\end{array}$} & \multirow{2}{*}{$\begin{array}{c}\text { Organic } \\
\text { matter (\%) }\end{array}$} \\
\hline & & & & & $\mathrm{CO}_{3}=$ & $\mathrm{HCO}_{3}{ }^{-}$ & $\mathrm{Cl}$ & $\mathrm{SO}_{4}=$ & $\mathrm{Ca}^{++}$ & $\mathrm{Mg}^{++}$ & $\mathrm{Na}_{-}^{+}$ & $\mathrm{K}^{+}$ & & \\
\hline 2017/ & $00-30$ & 7.84 & 1.17 & 32 & - & 0.50 & 8.40 & 1.11 & 1.80 & 0.90 & 7.10 & 0.20 & 1.00 & 0.40 \\
\hline 2018 & $30-60$ & 7.89 & 1.79 & 27 & - & 0.60 & 8.00 & 1.40 & 2.10 & 1.50 & 6.20 & 0.20 & 6.00 & 0.07 \\
\hline $2018 /$ & $00-30$ & 7.95 & 1.59 & 23 & - & 0.32 & 12.70 & 1.98 & 4.00 & 1.80 & 9.00 & 0.20 & 1.90 & 0.38 \\
\hline 2019 & $30-60$ & 7.85 & 1.81 & 25 & - & 0.45 & 15.40 & 2.15 & 5.60 & 2.00 & 10.20 & 0.20 & 1.30 & 0.32 \\
\hline
\end{tabular}

calcium superphosphate $\left(15.5 \% \mathrm{P}_{2} \mathrm{O}_{5}\right)$ was added to the soil. Nitrogen fertilizer was added after plants' emergence in the form of ammonium nitrate $33.5 \%$ at a rate of $180 \mathrm{~kg} / \mathrm{ha}^{-1}$ which was divided into five equal doses before the $1^{\text {st }}, 2^{\text {nd }}$, $3^{\text {rd }}, 4^{\text {th }}$, and $5^{\text {th }}$ irrigation. Potassium sulfate $\left(48.52 \% \mathrm{~K}_{2} \mathrm{O}\right)$ was divided into two equal doses of $120 \mathrm{~kg} / \mathrm{ha}^{-1}$ before the $1^{\text {st }}$ and $3^{\text {rd }}$ irrigation. Irrigation was carried out using the new sprinkler irrigation system where water was added every 5 days according to the amount of water irrigation used.

2.4. Plant Sample. Plant samples were gathered after 75 days from cultivation for measuring morphological parameters (plant height, tiller freshness, and dry weight). Samples of ten plants were gathered for biochemical analysis as photosynthetic pigments, total soluble sugars, proline, free amino acids, protein patterns, and molecular change.

At harvest (after 160 days from sowing), the following wheat characters were recorded on random patterns of ten girded plants in each treatment (grain yield and water productivity (WP) in $\mathrm{kg} \mathrm{m} / \mathrm{m} / \mathrm{ha}^{-1}$.
2.5. Irrigation Water Requirements. Two irrigation water requirements were calculated using the Penman-Monteith equation and crop coefficient according to [26]. The average amount of irrigation water applied with sprinkler irrigation system was 5950 and $4462.5 \mathrm{~m}^{3} \mathrm{ha}^{-1}$ season $^{-1}$ as $(100 \%$ (WW) and 75\% (WS)) for two seasons of 2017/2018 and 2018/2019, respectively.

The irrigation water requirements were calculated as follows:

$$
\mathbf{I W R}=\left[\frac{\mathrm{ET}_{0} \times K_{c} \times K_{r} \times I}{E a}+L R\right] \times 4.2,
$$

where we have the following:

IWR $=$ water irrigation quantities $\left(\mathrm{m}^{3} / \mathrm{ha}^{-1}\right)$

$\mathrm{ET}_{0}=$ evapotranspiration $\left(\mathrm{mm} \mathrm{day}{ }^{-1}\right)$

$K_{c}=$ crop coefficient

$K_{r}=$ reduction factor [27]

$I=$ the period between two irrigations, day

$\mathrm{Ea}=$ irrigation water efficiency, $90 \%$ 
$\mathrm{LR}=$ leaching requirement $=10 \%$ of the total water requirement applied to the treatment

2.6. Water Productivity (WP). WP was calculated according to Howell et al. [28]. Water productivity (WP) is realized as the relation between the grain yield and the quantity of irrigation water. The WP in $\mathrm{kg} / \mathrm{mm} / \mathrm{ha}$ was calculated by the following equation:

$$
\mathrm{WP}=\frac{\mathrm{Ey}}{\mathrm{Et}},
$$

where WP is the water productivity $\left(\mathrm{kg} / \mathrm{m}^{3}\right)$; Ey is the economical yield $\left(\mathrm{kg} \mathrm{ha}^{-1}\right)$; and Et is the total utilized of irrigation water, $\mathrm{m}^{3} \mathrm{ha}^{-1} /$ season.

2.7. Biochemical Analysis. Photosynthetic pigment content was determined according to the method described by Lichtenthaler and Buschmann [29]. Total soluble sugars were extracted and analyzed according to Prud' Homme et al. [30] and Yemm and Willis [31], respectively. Proline was assayed according to the method described by Bates et al. [32]. The free amino acid was determined according to the method described by Yeman et al. [33].

2.8. Protein Electrophoresis SDS-PAGE. A protein electrophoresis assay was conducted by sodium dodecyl sulfatepolyacrylamide gel electrophoresis (SDS-PAGE). SDSPAGE was performed according to Laemmli [34] as adapted by Studier [35].

\subsection{Molecular Marker}

2.9.1. Extraction of Genomic DNA. Bulk samples from young plant leaves of wheat varieties were soaked in liquid nitrogen for DNA extraction using 2\% (CTAB) cetyl trimethyl ammonium bromide [36].

\subsubsection{Sequence-Related Amplified Polymorphism (SRAP)} Analysis. A total of six primers were used to amplify DNA as previously described [37] (manufactured by Bioneer, with new technology certification from ATS Korea). The total reaction mixture was $25 \mu \mathrm{L}$ and contained 10X PCR buffer, $2 \mathrm{mM} \mathrm{MgCl}_{2}, 0.2 \mathrm{mM}$ dNTPs mixed, 10 pmol primers, $1.25 \mathrm{U}$ Taq polymerase, and about $150 \mathrm{ng}$ of genomic DNA. DNA-PCR amplification was performed in the thermal cycler (Biometra Inc., Germany). The temperature profile was as follows: initial denaturation at $94^{\circ} \mathrm{C}$ for $3 \mathrm{~min}$; followed by 35 cycles of denaturation temperature $94^{\circ} \mathrm{C}$ for $5 \mathrm{~min}$; annealing temperature of $37^{\circ} \mathrm{C}$ for $1 \mathrm{~min}$; extension temperature of $72^{\circ} \mathrm{C}$ for $1 \mathrm{~min}$; and final extension at $72^{\circ} \mathrm{C}$ for $5 \mathrm{~min}$.

The amplification products were separated on a $1.5 \%$ agarose gel containing $1 \mathrm{X}$ TBE buffer $(89 \mathrm{mM}$ Tris- $\mathrm{HCl}$, $89 \mathrm{mM}$ boric acid, $2.5 \mathrm{mM}$ EDTA, $\mathrm{pH} 8.3$ ) and $0.5 \mu \mathrm{g} / \mathrm{mL}$ ethidium bromide at $90 \mathrm{~V}$. Gels were analyzed by UVI Geltec version 12.4, 1999-2005 (USA).
2.10. Statistical Analysis. The data were subjected to statistical analysis of variance of the split-split plot design. Since the trend was similar in both seasons, the homogeneity test Bartlet's equation was applied, and the combined analysis of the two seasons was carried out according to the method. Duncan's multiple range test was estimated to compare the means at $P<0.05$ using SAS software (SAS Institute Inc. 2002; Steel and Torrie [38]).

\section{Results and Discussion}

3.1. Growth Parameters and Grain Yield of Wheat. The growth parameters, grain yield, and water productivity of both wheat cultivars Gimeza 12 and Sids 13 after treatment with nano- $\mathrm{TiO}_{2}$ or nano- $\mathrm{ZnO}$ (5 and $10 \mathrm{mg} / \mathrm{L}$ ) and grown under different water irrigation requirements $(100 \% \mathrm{WW}$ and $75 \% \mathrm{WS}$ ) are presented in Figures 2 and 3. All morphological studied traits (height of plant, tiller fresh, and dry weights) were significantly decreased by water stress $(P \leq 0.05)$. Also, grain yield/ha was detected as compared to control plants (WW) in both cultivars. Water stress significantly decreased grain yield by $14.8 \%$ and $11.5 \%$ compared to that of the well-watered Gimeza 12 and Sids 13 cultivars, respectively (Figure 3(a)). Statistical analysis showed that application of nano- $\mathrm{TiO}_{2}$ or nano- $\mathrm{ZnO}$ ( 5 and $10 \mathrm{mg} / \mathrm{L}$ ) on water-stressed and well-watered plants induced a significant increase in the morphological parameters, grain yield, and crop water productivity (CWP) of both wheat cultivars (Figures 2 and 3). Particularly, $10 \mathrm{mg} \mathrm{L}^{-1} \mathrm{TiO}_{2}$ and $\mathrm{ZnO}$ nanoparticles treatments recorded grain yield of 6.40and 6.30-ton/ha, respectively, compared to the untreated plant $(5.39 \mathrm{~kg} /$ ton $)$ in the Gimeza 12 cultivar. While, for the Sids 13 cultivar, the $10 \mathrm{mg} \mathrm{L}^{-1}$ of both treatments recorded grain yield of 6.09- and 6.01-ton $\mathrm{ha}^{-1}$, respectively, compared to the untreated plant $(4.94 \mathrm{~kg} / \mathrm{ton})$. These increments in grain yield of wheat plants in response to application of $10 \mathrm{mg} / \mathrm{L}$ of either nano- $\mathrm{TiO}_{2}$ or nano- $\mathrm{ZnO}$ reached $27 \%$ and $26 \%$ in the Gimeza 12 and $23 \%$ and $16 \%$ in the Sids 13 , respectively, over the control plants under WS. The results also cleared that the Gimeza 12 cultivar surpassed the Sids 13 cultivar in grain yield $\mathrm{ha}^{-1}$. Also, exposure of plants to WS increased significantly the productivity of water as compared with control plants grown under the WW level in two cultivars (Figure 3(b)). Water stress led to a significant increase in WP by $13.6 \%$ and $18.0 \%$ compared to that of the corresponding WW control in both the Gimeza 12 and Sids 13 cultivars, respectively. Application of nano- $\mathrm{TiO}_{2}$ or nano$\mathrm{ZnO}$ with various concentrations on wheat plants significantly promoted water productivity at both water levels (WW and WS) as compared with the untreated plant in the Gimeza 12 and Sids 13. The increment in WP due to $\mathrm{TiO}_{2}$ and $\mathrm{ZnO}$ at $10 \mathrm{mg}^{-1}$ reached (18.8 and 16.7\%) in the WW control and (27.1 and 26.0\%) under the WS treatment in Gimeza 12 and (23.4 and 21.7\%) in the WW control and (23.4 and 17.0\%) under the WS treatment in Sids 13.

Lack of water from the plant cells due to water-deficits decreases wheat growth and yield production. Water deficiency decreased the plant dry weight and affected on the delivery of carbohydrates to produced grains [39]. 


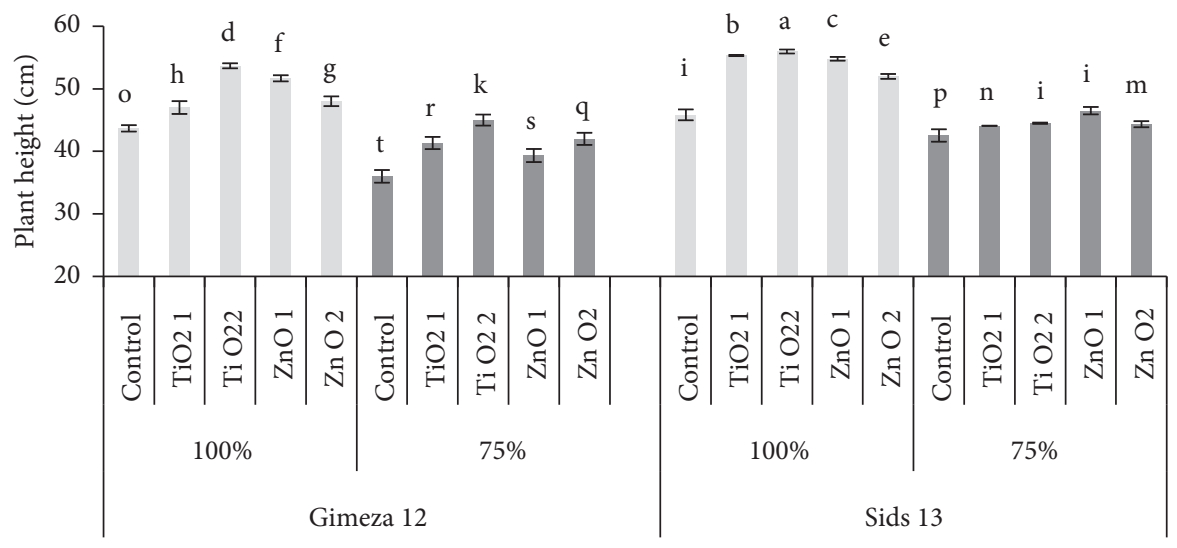

(a)

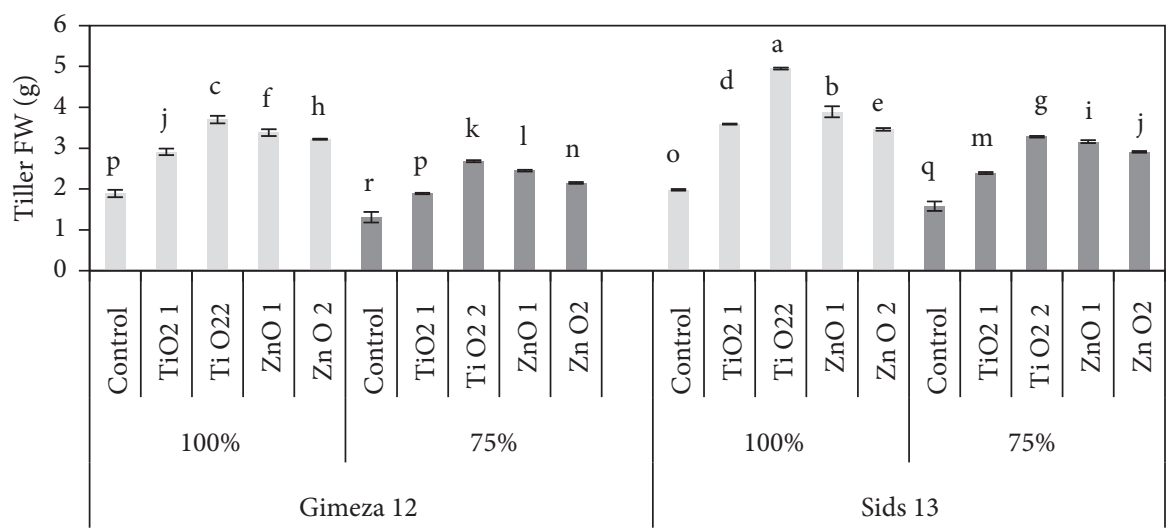

(b)

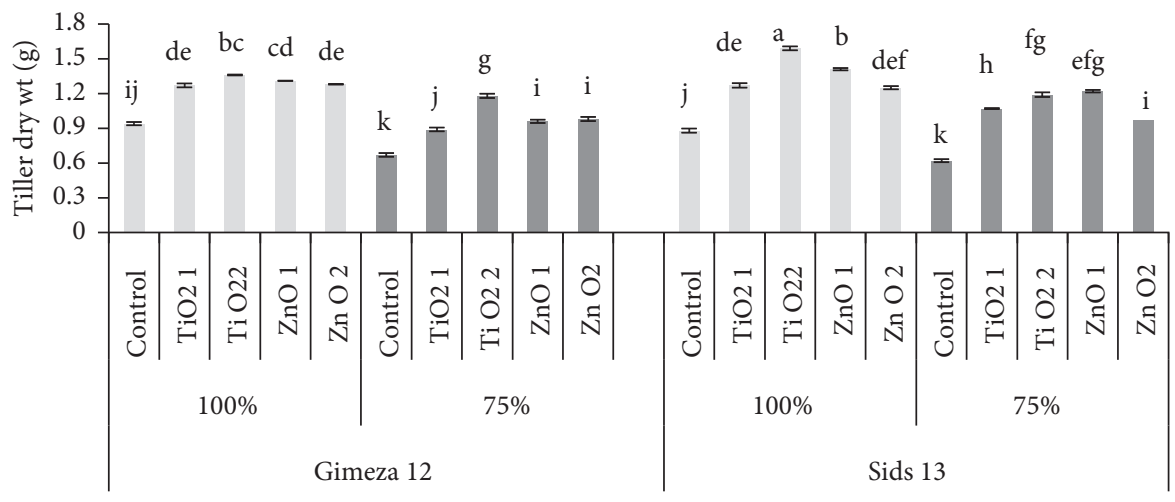

(c)

Figure 2: Effect of different concentrations of nano- $\mathrm{TiO}_{2}$ or nano- $\mathrm{ZnO}$ ( 5 and $10 \mathrm{mg} / \mathrm{L}$ ) on plant height (a), tiller fresh weight (b), and tiller dry weight (c) at 75 days from sowing of both wheat cultivars (Gimeza 12 and Sids 13) subjected to different levels of water irrigation requirement (combined analysis of two seasons). $\mathrm{TiO}_{2} 1=5 \mathrm{mg} / \mathrm{L}, \mathrm{TiO}_{2} 2=10 \mathrm{mg} / \mathrm{L}, \mathrm{ZnO} 1=5 \mathrm{mg} / \mathrm{L}$, and $\mathrm{ZnO} 2=10 \mathrm{mg} / \mathrm{L}$.

The enhancement of plant growth is perhaps related to the promoted photosynthetic pigments by $\mathrm{n}-\mathrm{TiO}_{2}$ treatment. Yang et al. [11] stated that $\mathrm{TiO}_{2}$ nanoparticles increase spinach growth via improving nitrogen metabolism which encourages the absorption of nitrate in plants and accelerates the conversion of inorganic nitrogen into organic nitrogen, thus increasing the fresh and dry weights. Moreover, Jaberzadeh et al. [40] found that $\mathrm{TiO}_{2}$ NPs improved the growth and yield components of wheat plants grown under water deficit. Nano- $\mathrm{TiO}_{2}$ modulates ROS-dependent signalling pathway(s), so it can regulate plant growth [41]. Also, $\mathrm{TiO}_{2}-\mathrm{NPs}$ treatment stimulates plant metabolic activities as a nanonutrient fertilizer and improves biomass production [42]. Moreover, Owolade et al. [43] stated that treatment with nano$\mathrm{TiO}_{2}$ improved the seed yield of cowpea (Vigna unguiculata (L.)) because of increased photosynthetic rate and the activities of an antioxidant enzyme like catalase and peroxidase. In addition, Shallan et al. [44] proved that treatment with nano- $\mathrm{TiO}_{2}$ could stimulate the drought tolerance of cotton plants and enhance the yield characteristics. 


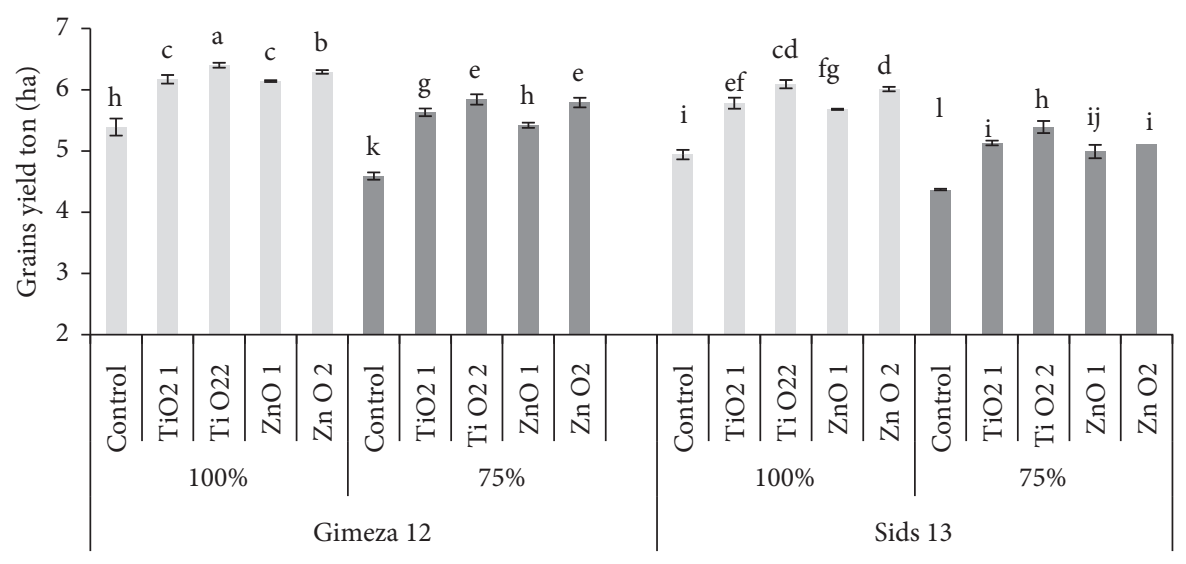

(a)

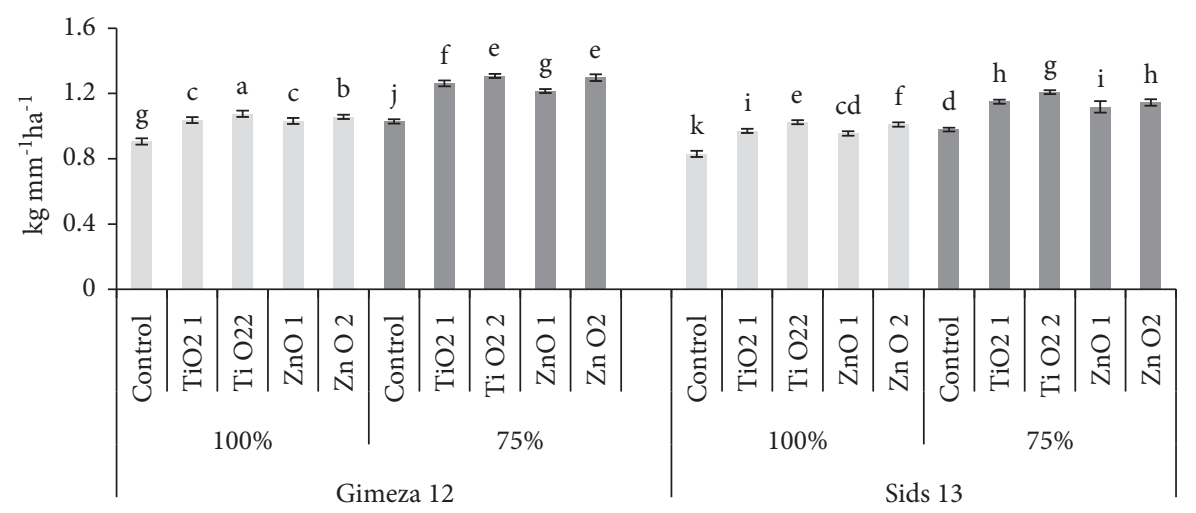

(b)

Figure 3: The effect of different concentrations of nano- $\mathrm{TiO}_{2}$ or nano- $\mathrm{ZnO}(5$ and $10 \mathrm{mg} / \mathrm{L}$ ) on grain yield (a) and water productivity (b) at harvest of both wheat cultivars (Gimeza 12 and Sids 13) subjected to different levels of water irrigation requirement (combined analysis of two seasons). $\mathrm{TiO}_{2} 1=5 \mathrm{mg} / \mathrm{L}, \mathrm{TiO}_{2} 2=10 \mathrm{mg} / \mathrm{L}, \mathrm{ZnO} 1=5 \mathrm{mg} / \mathrm{L}$, and $\mathrm{ZnO} 2=10 \mathrm{mg} / \mathrm{L}$.

Zinc oxide nanoparticles (ZnONPs) increase plant growth and development in the wheat plant [45]. Zinc has an important role in the regulation of hormone metabolism via alteration in auxin levels through tryptophan biosynthesis and activating cell division and enlargement [46]. $\mathrm{Zn}$ induced the enhancement in protein synthesis [47] and scavenged free oxygen radicals. It appears to influence the capability for water uptake and transport in plants and decrease the negative influences of salt stress [48]. Zinc plays a vital role in chlorophyll biosynthesis, carbohydrates, lipids, proteins, as a cofactor in some specific enzymes (DNA and RNA polymerase), and the synthesis of some hormones [47].

The ratio of grain yield to water used is linked with crop water productivity (WP) in general and is inversely proportional with the intensity of water stress. Plants exposed to $75 \%$ of WIR caused significant increases in water productivity as compared with control plants (100\% WIR) in both cultivars. In this regard, the WP is stimulated under water stress [49]. Through water stress, stomatal closure leads to reduced leaf conductance, photosynthesis, and transpiration. Because of the slight response of leaf conductance to decreased leaf water potential, the more conservative usage of water results in higher WP in water-lacking plants, which might be a mechanism for improving resource use efficacy [50]. WP is an important physiological adaptation mechanism that can progress crop productivity under water deficiency [51]. Stimulation in water productivity in response to various treatments suggests that the plant exploits various mechanisms to reduce water deficits, through decreasing its water consumption and preserving excess biomass [49].

3.2. Photosynthetic Pigments. Exposure of plants to the WS (75\%) in the field conditions significantly decreased the contents of photosynthetic pigments as compared with control plants WW (100\%) in both cultivars (Figure 4). The impact of $\mathrm{TiO}_{2}$ or $\mathrm{ZnO}$ NPs ( 5 and $10 \mathrm{mg} / \mathrm{L}$ ) increased significantly the photosynthetic pigments on wheat plants under various water levels when compared to the corresponding untreated plants. The highest values in total photosynthetic pigments were recorded through the application with $10 \mathrm{mg} \cdot \mathrm{L}^{-1}$ nano- $\mathrm{TiO}_{2}(55.8 \%$ and $55.3 \%)$ in response to the Gimeza 12 cultivar and using $10 \mathrm{mg} / \mathrm{L}$ nano$\mathrm{ZnO}$ (52.43 and 49.41) in the Sids 13 at WW and WS, respectively. It is notable that the Gimeza12 cultivar surpassed the Sids 13 cultivar in all photosynthetic pigments.

Water stress induced a significant decrease in photosynthetic pigments due to stomata closure and Rubisco inhibition [52]. Carotenoid contents were significantly 


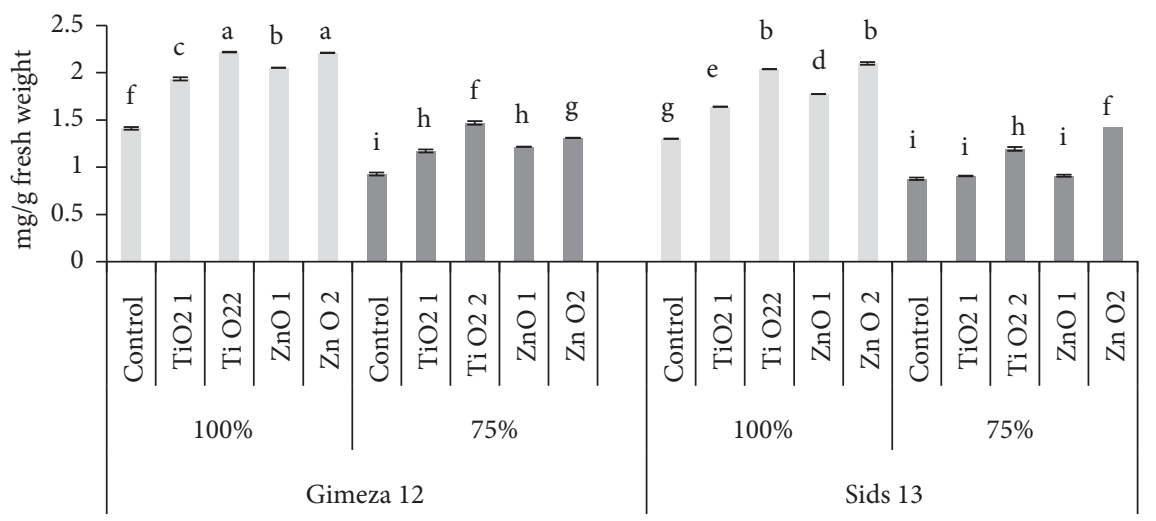

(a)

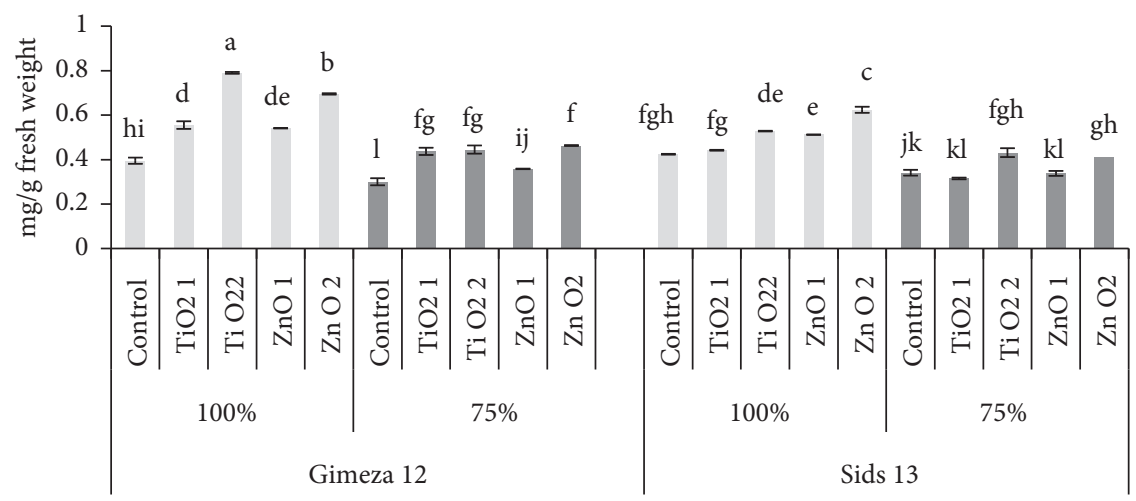

(b)

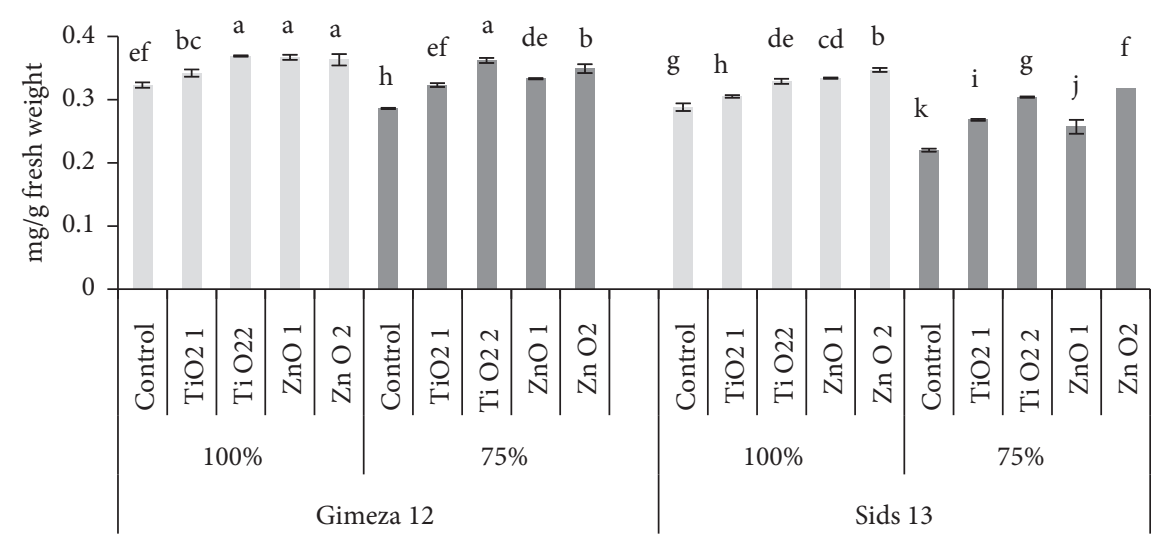

(c)

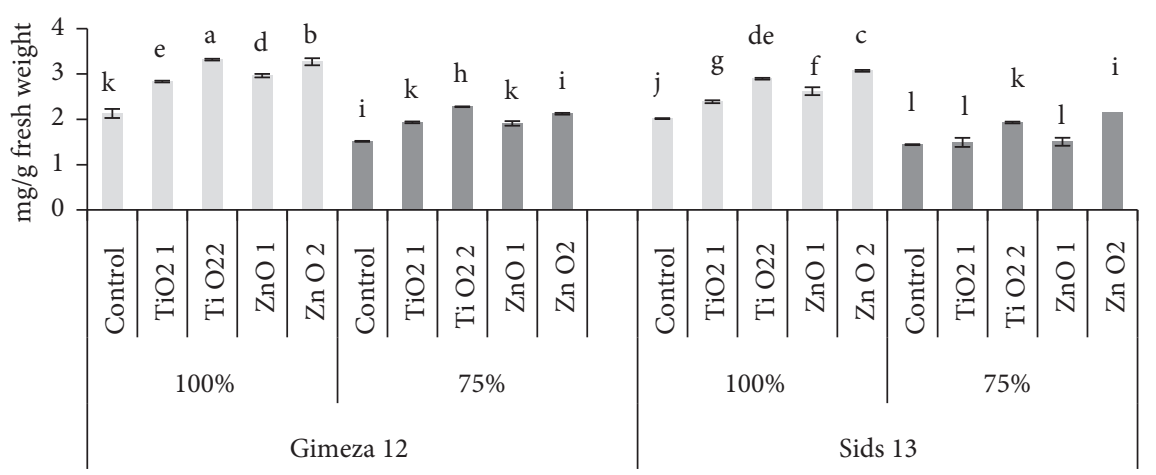

(d)

Figure 4: The effect of different concentrations of nano- $\mathrm{TiO}_{2}$ or nano- $\mathrm{ZnO}$ (5 and $10 \mathrm{mg} / \mathrm{L}$ ) on chlorophyll a (a), chlorophyll b (b), carotenoids (c), and total pigments (d) of both wheat cultivars (Gimeza 12 and Sids 13) subjected to different levels of water irrigation requirement at 75 days from sowing. $\mathrm{TiO}_{2} 1=5 \mathrm{mg} / \mathrm{L}, \mathrm{TiO}_{2} 2=10 \mathrm{mg} / \mathrm{L}, \mathrm{ZnO} 1=5 \mathrm{mg} / \mathrm{L}$, and $\mathrm{ZnO} 2=10 \mathrm{mg} / \mathrm{L}$. 
increased in both cultivars under treatment with nano- $\mathrm{TiO}_{2}$ or nano- $\mathrm{ZnO}$, in combination with WS when compared with control plants. The increased percentage reached $19.8 \%$ and $19.2 \%$ in the Gimeza 12 and $30.0 \%$ and $30.7 \%$ in the Sids 13 at nano- $\mathrm{TiO}_{2}$ or nano-ZnO, respectively (Figure 4). Carotenoids have an important function as a free radical scavenger [53].

Nano- $\mathrm{TiO}_{2}$ increased aged seeds' vigor and photosynthetic pigments' biosynthesis promotes the activity of ribulose 1, 5-bisphosphate carboxylase (Rubisco) and rises net photosynthesis in parallel to stimulating plant growth and proliferation [11]. They also added that, it promoted the absorbance of light, hurried the conversion and transport of light energy, kept the chloroplasts from senility, and extended the photosynthetic period of the chloroplasts. Moreover, Shallan et al. [44] found that $\mathrm{TiO}_{2}$ nanoparticles increase photosynthetic pigments in cotton plants under drought stress. Additionally, $\mathrm{Ze}$ et al. [54] stated that $\mathrm{n}-\mathrm{TiO}_{2}$ may encourage light absorption by chloroplasts through regulation of genes related to light-harvesting complex II, which is in line with our observation of an increase of soluble sugars upon $\mathrm{n}-\mathrm{TiO}_{2}$ addition (Figure 4).

Tumburu et al. [55] stated that nano- $\mathrm{TiO}_{2}$-induced genes were generally associated with photosynthetic metabolisms that were proved in a genome-wide transcriptome on Arabidopsis thaliana leaves. Also, Ze et al. [54] stated that $\mathrm{n}-\mathrm{TiO}_{2}$ may encourage light absorption by chloroplasts by regulation of genes concerning light harvesting complex II, which is in harmony with our result of an increase of TSS nano- $\mathrm{TiO}_{2}$ (Figure 4).

In response to nano- $\mathrm{ZnO}, \mathrm{El}$ Bassiouny et al. [45] observed that when treated with Triticum aestivumn L. with low concentrations of nano- $\mathrm{ZnO}$ ( 5 and $10 \mathrm{mg} \cdot \mathrm{L}^{-1}$ ), significantly raised photosynthetic pigments. In this regard, Raliya and Tarafdar [56] concluded that ZnONPs improved significantly growth, chlorophyll and protein synthesis in clusterbean plants. Zinc has an important role in the synthesis of indoleacetic acid (IAA) from tryptophan and other biochemical reactions required for chlorophyll and carbohydrate metabolism. In this regard, Sun et al. [57] found that, nano- $\mathrm{ZnO}$ improved the chloroplast and mitochondria stabilization which preserves the photosynthetic apparatus under water stress.

3.3. The Change in Organic Solutes. The influence of water deficit and different treatments of $\mathrm{TiO}_{2}$ or $\mathrm{ZnO}$ nanoparticles ( 5 and $10 \mathrm{mg} / \mathrm{L}$ ) on some metabolites (total soluble sugars (TSS), proline (Pro), and free amino acids (FAA)) in two wheat cultivars (Gimeza 12 and Sids 13) is presented in Figure 5. Under water stress, plants accumulate higher amounts of TSS, Pro, and FAA content in both wheat cultivars by $24.2 \%, 112.2 \%$, and 22.7 in the Gimeza 12 and $19.7 \%$, $107.7 \%$, and 25.3 in Sids 13, respectively, compared to the corresponding WW control. The application of nano- $\mathrm{TiO}_{2}$ or nano- $\mathrm{ZnO}(5$ and $10 \mathrm{mg} / \mathrm{L})$ significantly increased $(P<0.05)$ the TSS, Pro, and FAA in WW or WS plants when compared to the corresponding controls in both cultivars. Results in Figure 5 showed that higher concentrations of either nano-
$\mathrm{TiO}_{2}$ or nano- $\mathrm{ZnO}\left(10 \mathrm{mg}^{-1}\right)$ were more efficient in enhancing TSS, Pro, and FAA than lower concentrations under WS in both cultivars Gimeza 12 and Sids 13.

Osmoprotectant accumulation is a regular response of plants exposed to drought [49]. They added that the role of TSS, Pro, and FAA accumulation promote cells tolerance under water stress through stimulation of osmotic pressure in the cytoplasm and relative water content which are important for plant growth and development.

The application of nano- $\mathrm{TiO}_{2}$ on wheat cultivars under drought stress conditions increased the content of total soluble sugars [58]. Moreover, Khater [59] reported that foliar application of coriander with $\mathrm{TiO}_{2}-\mathrm{Nps}$ at 2, 4, and $6 \mathrm{mg} / \mathrm{L}$ significantly raised FAA and TSS contents. Shallan et al. [44] found that drought stress with nano- $\mathrm{TiO}_{2}$ caused an increase in Pro, FAA, and TSS in cotton plants. Also, Mohammadi et al. [60] showed that $\mathrm{TiO}_{2}$ induced accumulation of proline that is responsible for protecting cell turgor under different stresses, especially drought stress. Moreover, Abdel Latef et al. [61] showed that broad bean plants treated with $\mathrm{n}-\mathrm{TiO}_{2}$ at $10 \mathrm{mg} / \mathrm{L}$ led to significant increases in TSS, Pro, and FAA levels under salinity stress.

In this study, the nano- $\mathrm{ZnO}$ application might cause increases in TSS, Pro, and FAA concentrations under water stress, which indicates that nano- $\mathrm{ZnO}$ can improve osmotic regulation. Amira et al. [62] established that ZnO NPs treatment raised the TSS and Pro concentrations which are associated with the salt tolerance in maize. Abdel Latef et al. [19] and El-Bassiouny et al. [63] stated that zinc oxide nanoparticle treatment augmented the contents of compatible solutes (TSS, Pro, and FAA) in lupine and wheat plants under salinity stress.

\subsection{Protein Electrophoresis SDS-PAGE. SDS-PAGE of total} protein extracted from wheat leaves treated with nanoparticles is shown in Figure 6 and Table 2. In this study, it was observed that treatment with $\mathrm{TiO}_{2}$ or $\mathrm{ZnO}$ nanoparticles led to a slight increase or decrease in the protein banding pattern as compared with the control. A total number of 13 bands were scored ranging from 8 to $163 \mathrm{kDa} ; 8$ of these were monomorphic $(61.54 \%)$, while the other five bands were polymorphic (38.46\% polymorphism). The highest number of bands was shown in Sids13 in control WW and WS (13 subunits), followed by the plants treated with nano- $\mathrm{TiO}_{2}$ and nano- $\mathrm{ZnO}$ (12 subunits), except for nano-ZnO at WS (9 subunits). However, in Gimeza 12, the control WS plant recorded the two new polypeptides at the molecular weights (MWs) of 28 and $18 \mathrm{kDa}$ and disappeared at $51 \mathrm{kDa}$ as compared with the control WW plant. Moreover, Gimeza 12 treated with $\mathrm{TiO}_{2}$ and $\mathrm{ZnO}$ nanoparticles stimulates the appearance of new bands at the $\mathrm{MW}$ of $28 \mathrm{kDa}$ in $\mathrm{WW}$ and WS as compared with control WW. While in WS, nano- $\mathrm{TiO}_{2}$ and nano- $\mathrm{ZnO}$ recorded the new polypeptides at $18 \mathrm{kDa}$ not found in the same treatment in WW. Also, Gimeza 12 treated with nano- $\mathrm{TiO}_{2}$ led to the disappearance of two bands with MWs of 163 and $51 \mathrm{kDa}$ in WS when compared with the control and nano- $\mathrm{TiO}_{2}$ in WW. On the contrary, at Sids 13 , there is no difference between the treatments in $\mathrm{WW}$ 


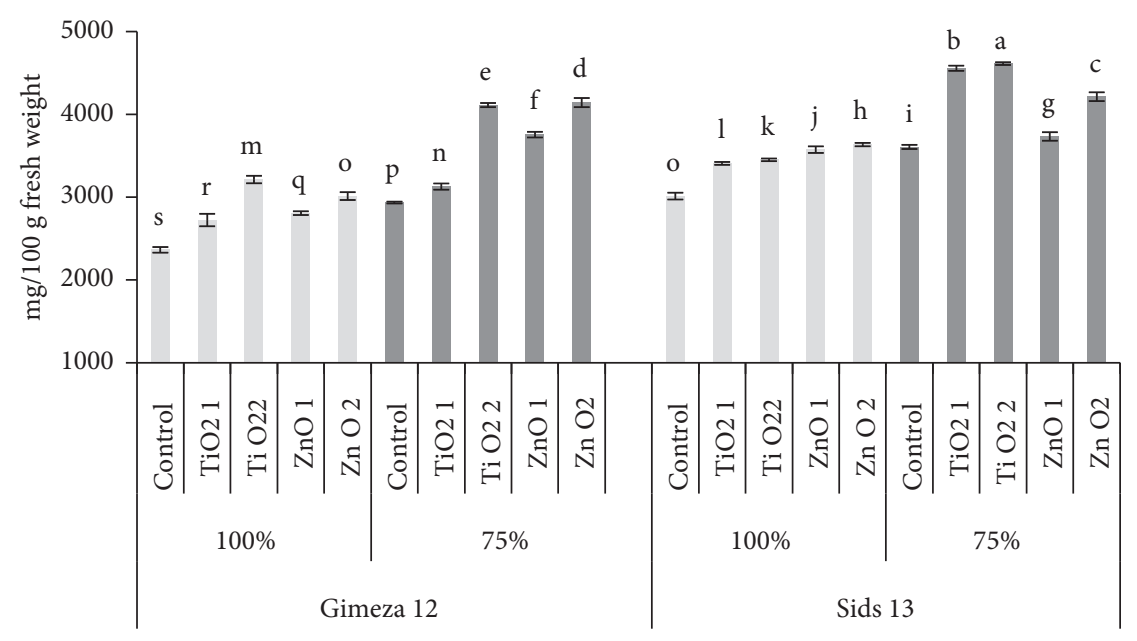

(a)

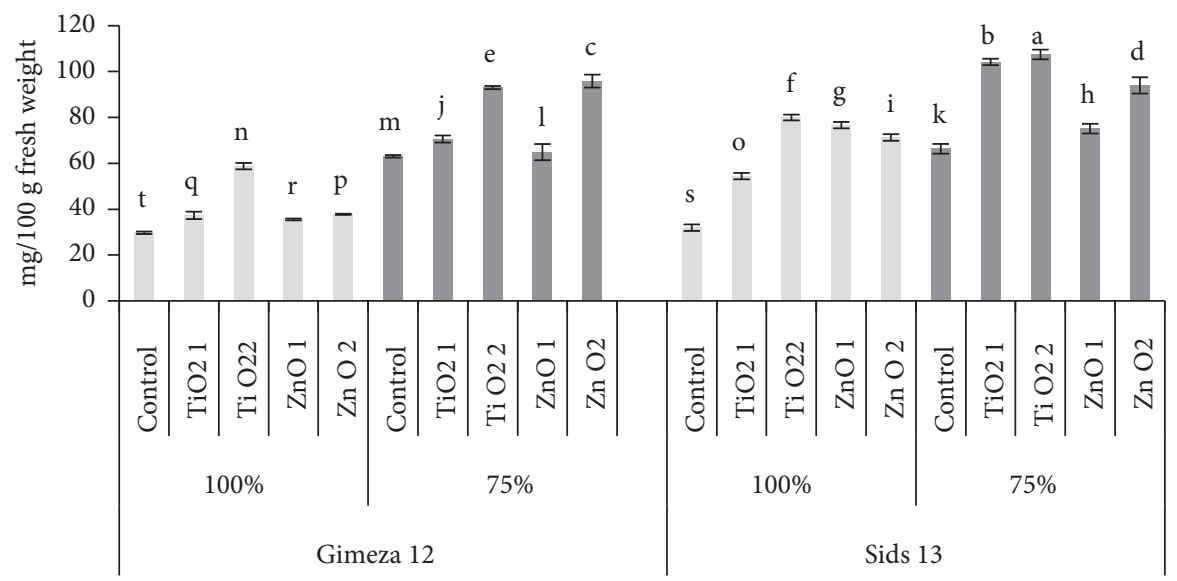

(b)

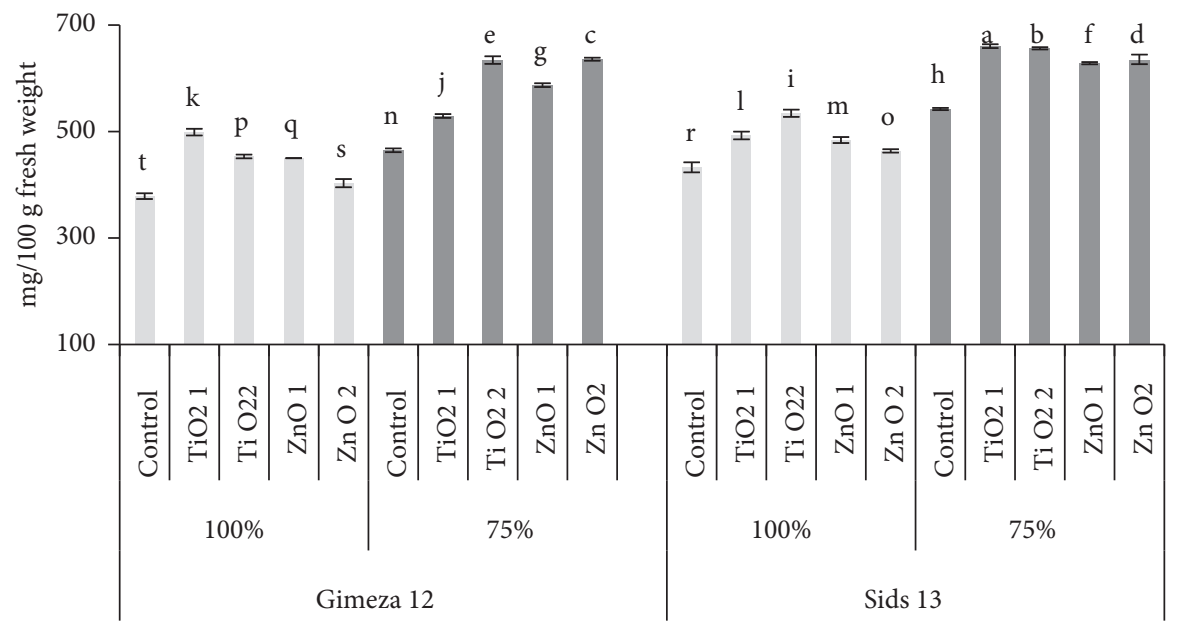

(c)

FIgURE 5: The effect of different concentrations of nano- $\mathrm{TiO}_{2}$ or nano- $\mathrm{ZnO}(5$ and $10 \mathrm{mg} / \mathrm{L})$ on total soluble sugar (a), proline (b), and free amino acids (c) of both wheat cultivars (Gimeza 12 and Sids 13) subjected to different levels of water irrigation requirement at 75 days from sowing. $\mathrm{TiO}_{2} 1=5 \mathrm{mg} / \mathrm{L}, \mathrm{TiO}_{2} 2=10 \mathrm{mg} / \mathrm{L}, \mathrm{ZnO} 1=5 \mathrm{mg} / \mathrm{L}$, and $\mathrm{ZnO} 2=10 \mathrm{mg} / \mathrm{L}$.

and WS except for the nano- $\mathrm{ZnO}$ at WS that disappears the polypeptides at MWs of 163,51 , and $18 \mathrm{kDa}$. Moreover, the protein at $\mathrm{Mw} 42 \mathrm{kDa}$ was presented only in the control plants at WW and WS in Sids 13. In addition, the increase and decrease in protein bands depend on the wheat cultivar. Data also recorded that Sids 13 cultivar was surpassed by Gimeza 12 with a slight increase in density, intensity, and number of protein bands. 


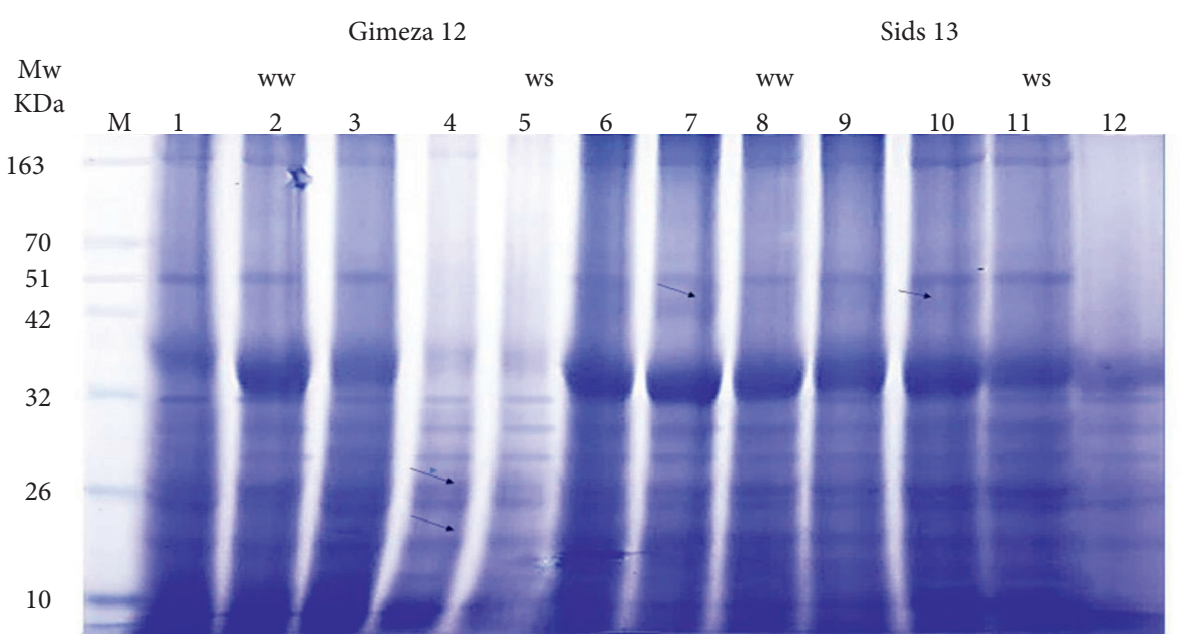

FIGURE 6: The change of protein bands (marked by arrowheads) in response to different treatments on wheat cultivars (Gimeza 12 and Sids 13) with nano- $\mathrm{TiO}_{2}$ or nano- $\mathrm{ZnO}\left(10 \mathrm{mg} \cdot \mathrm{L}^{-1}\right)$ at different water irrigation requirements (WW and WS) at 75 days from sowing. Electrograph of soluble protein pattern by one-dimensional SDS-PAGE. Each lane contains equal amounts of protein extracted from the plant. Protein bands in the gel were visualized by Coomassie Blue stain. Lane M: Marker, Gimeza 12 (lane 1: WW, lane 2: $\mathrm{WW}+$ nano-TiO 2 , lane 3: $\mathrm{WW}+$ nano- $\mathrm{ZnO}$, lane 4: $\mathrm{WS}$, lane 5: WS + nano- $\mathrm{TiO}_{2}$, and lane 6: $\mathrm{WS}+$ nano- $\mathrm{ZnO}$ ); Sids 13 (lane 7: $\mathrm{WW}$, lane 8: $\mathrm{WW}^{-}$nano- $\mathrm{TiO}_{2}$, lane 9: $\mathrm{WW}+\mathrm{NO}$, lane 10: WS, lane 11:WS + nano- $\mathrm{TiO}_{2}$, and lane $12: \mathrm{WS}+$ nano- $\left.\mathrm{ZnO}\right)$.

TABLE 2: The effect of nano- $\mathrm{TiO}_{2}$ or nano- $\mathrm{ZnO}(10 \mathrm{mg} / \mathrm{L})$ on protein banding patterns of SDS-PAGE of both wheat cultivars (Gimeza 12 and Sids 13) subjected to different levels of water irrigation requirement at 75 days from sowing (+: present and -: absent).

\begin{tabular}{|c|c|c|c|c|c|c|c|c|c|c|c|c|c|}
\hline \multirow{4}{*}{ No. } & \multirow{4}{*}{$\begin{array}{l}\mathrm{Mw} \\
\mathrm{KDa}\end{array}$} & \multicolumn{6}{|c|}{ Gimeza 12} & \multicolumn{6}{|c|}{ Sids 13} \\
\hline & & \multicolumn{3}{|c|}{$100 \%$ WIR } & \multicolumn{3}{|c|}{ 75\% WIR } & \multicolumn{3}{|c|}{ 100\% WIR } & \multicolumn{3}{|c|}{ 75\% WIR } \\
\hline & & $\mathrm{C}$ & $\mathrm{TiO}_{2}$ & $\mathrm{ZnO}$ & $\mathrm{C}$ & $\mathrm{TiO}_{2}$ & $\mathrm{ZnO}$ & $\mathrm{C}$ & $\mathrm{TiO}_{2}$ & $\mathrm{ZnO}$ & $\mathrm{C}$ & $\mathrm{TiO}_{2}$ & $\mathrm{ZnO}$ \\
\hline & & 1 & 2 & 3 & 4 & 5 & 6 & 7 & 8 & 9 & 10 & 11 & 12 \\
\hline 1 & 163 & + & + & + & + & - & + & + & + & + & + & + & - \\
\hline 2 & 51 & + & + & + & - & - & + & + & + & + & + & + & - \\
\hline 3 & 42 & - & - & - & - & - & - & + & - & - & + & - & - \\
\hline 4 & 36 & + & + & + & + & + & + & + & + & + & + & + & + \\
\hline 5 & 32 & + & + & + & + & + & + & + & + & + & + & + & + \\
\hline 6 & 30 & + & + & + & + & + & + & + & + & + & + & + & + \\
\hline 7 & 28 & - & + & + & + & + & + & + & + & + & + & + & + \\
\hline 8 & 26 & + & + & + & + & + & + & + & + & + & + & + & + \\
\hline 9 & 24 & + & + & + & + & + & + & + & + & + & + & + & + \\
\hline 10 & 20 & + & + & + & + & + & + & + & + & + & + & + & + \\
\hline 11 & 18 & - & - & - & + & + & + & + & + & + & + & + & - \\
\hline 12 & 10 & + & + & + & + & + & + & + & + & + & + & + & + \\
\hline 13 & 8 & + & + & + & + & + & + & + & + & + & + & + & + \\
\hline \multicolumn{2}{|c|}{ Bands no. $=13$} & 10 & 11 & 11 & 11 & 10 & 12 & 13 & 12 & 12 & 13 & 12 & 9 \\
\hline
\end{tabular}

In leaves of Gimeza 12 and Sids 13 cultivars grown under water deficit, the alteration in protein electrophoretic patterns was recorded with several kinds of alterations. Some protein bands appeared in the synthesis of the novel set of protein bands. In this regard, El-Bassiouny et al. [64] and Sadak et al. [49] approved these obtained results in sunflower and wheat plants under drought conditions, respectively. They added that these proteins have a stimulative osmoprotectant role and a preserving cellular structures. Also, Abdallah [58] suggested that groups of membrane-bound proteins are involved in renovating membrane damage caused by water deficit, managing the permeability of the membrane to water, and influencing water movement through the tissues and cells, consequently maintaining their normal turgidity.
These results were similar to Hajra and Mondal [65] who demonstrated that the Cicer arietinum treated with $\mathrm{ZnO}$ and $\mathrm{TiO}_{2}$ NPS increased the protein content. Dubchak et al. [66] reported that silver and titanium NPs have a great surface area in proportion to capacity rate which is responsible for the promotion of their bioactivity, bioavailability, and biochemical metabolism. In this connection, Priyanka and Venkatachalam [67] observed that the treatment of the cotton plant with $\mathrm{ZnO}$ nanoparticles improved the total soluble protein (TSP) content compared to the untreated plant. Despite this, the protein content decreased slightly at a higher dose. Similarly, the ZnO NPs at lower doses improved the TSP content in the pea [68]. Moreover, Priyanka and Venkatachalam [67] mentioned that the upregulated expression of proteins protects the plant cells from any 
TABLE 3: SRAP-PCR analysis of two wheat cultivars (Gimeza 12 \& Sids 13) treated with nano TiO2 or ZnO (10mg/l) subjected to different levels of water irrigation requirments at 75 days from sowing.

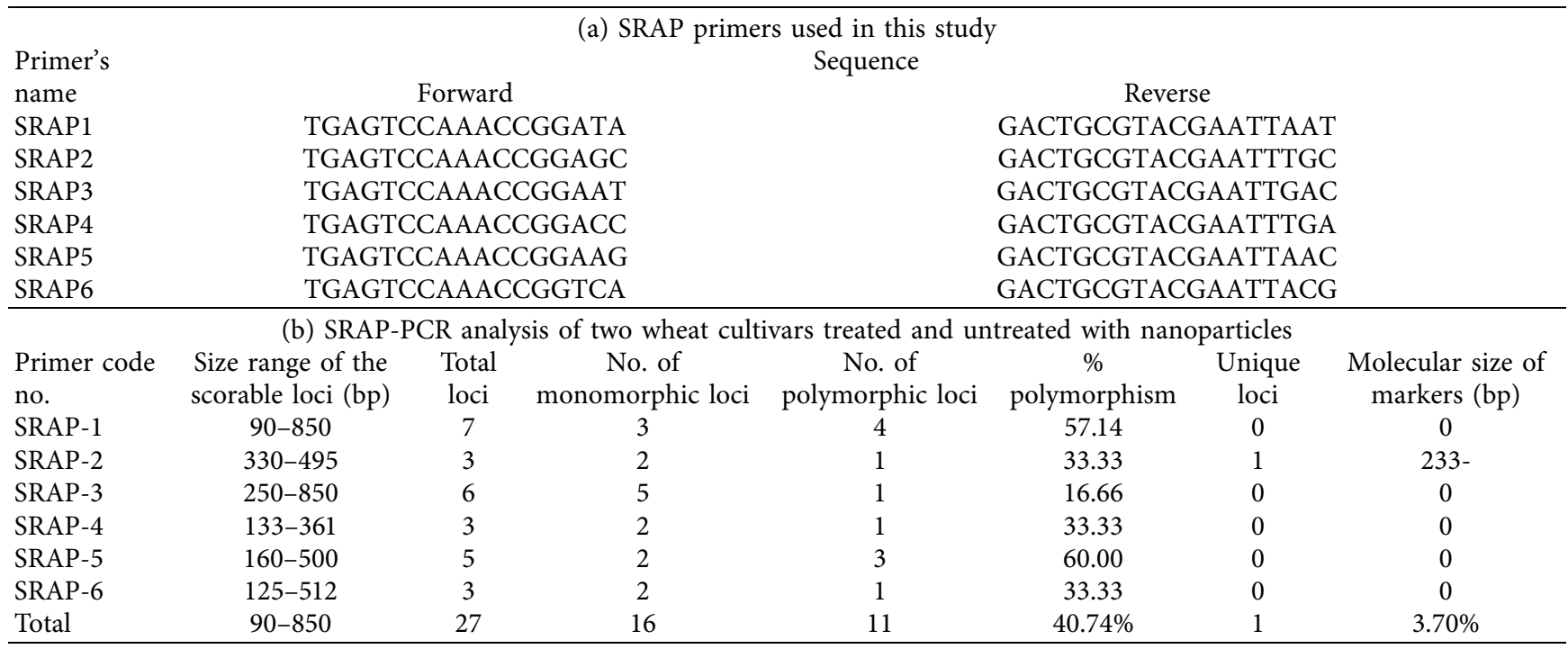

oxidative stress induced by nanofertilizer in the cotton plants. Recently, El-Bassiouny et al. [63] found that nano$\mathrm{ZnO}$ at 5 and $10 \mathrm{mg} \cdot \mathrm{L}^{-1}$ could be considered as positive markers at MWs of 51 and $40 \mathrm{kDa}$ and stimulated responsive protein band number and density in wheat cultivars.

\subsection{Molecular Markers Analysis}

3.5.1. Genetic Diversity Based on SRAP Markers. The experimental design with the two cultivars (Gimeza 12 and Sids 13) was treated with nano- $\mathrm{TiO}_{2}$ or nano- $\mathrm{ZnO}(10 \mathrm{mg} /$ L). Genomic DNA from the leaves of control and various treatments was amplified by utilizing six SRAP primers. Sequence-related amplified polymorphism (SRAP) is a powerful technique for determining genetic changeability due to its high reproducibility, discriminatory power, and high polymorphism rate in many genetic studies.

A total number of 27 fragments were amplified via six influential SRAP-PCR primers (4.5 loci per primer), ranging from 90 to $850 \mathrm{bp}$ (Table 3 and Figure 7). Sixteen alleles were monomorphic bands (59.25\%), whereas 11 loci were polymorphisms (40.74\%). The number of alleles per primer differs from three by SRAP-2, SRAP-4, and SRAP-9 to seven by SRAP-1. Primer SRAP-5 obtained the highest number of polymorphisms (60\%), followed by primer SRAP-1 (57.14\%). Also, primer SRAP-3 recorded the lowest number of polymorphism (16.66\%). Except 1 out of the 27 was a unique band (3.70\%). One band with a molecular size of $-233 \mathrm{bp}$ disappeared in the Gimeza 12 cultivar treated with WS + nano$\mathrm{TiO}_{2}$ and was revealed in the other treatments using primer SRAP-2. Consequently, this band may be considered a negative marker. It is noted that WS + nano- $\mathrm{TiO}_{2}$ in Gimeza 12 cultivar and WS in Sids 13 cultivar treatments exhibited one band of $850 \mathrm{bp}$ and was absent in the other treatments using primer SRAP-1. On the contrary, one band with a molecular size of $330 \mathrm{bp}$ was absent in $\mathrm{WW}+$ nano- $\mathrm{TiO}_{2}, \mathrm{WW}+$ nano- $\mathrm{ZnO}$ in the Gimeza 12 cultivar, $\mathrm{WW}+$ nano- $-\mathrm{TiO}_{2}, \mathrm{WW}+$ nano- $\mathrm{ZnO}$,
$\mathrm{WS}+$ nano- $\mathrm{TiO}_{2}$, and $\mathrm{WS}$ + nano- $\mathrm{ZnO}$ in the Sids 13 cultivar, respectively, using primer SRAP-1. Also, one band of $290 \mathrm{bp}$ was scored in the treatments $\mathrm{WW}, \mathrm{WW}+$ nano- $\mathrm{TiO}_{2}$, $\mathrm{WW}+$ nano-ZnO, WS in the Gimeza 12 cultivar, WS from the Sids13 cultivar, and was absent with the other treatments. Moreover, with a molecular size of $283 \mathrm{bp}$, one band from $\mathrm{WS}+$ nano- $\mathrm{TiO}_{2}$ and WS + nano- $\mathrm{ZnO}$ in the Gimeza 12 cultivar was absent while revealed in the other treatments. One band was revealed with $850 \mathrm{bp}$ in the Gimeza 12 treated with WS and WS + nano- $\mathrm{TiO}_{2}$, and the Sids 13 treated with WS, while absent in the other treatments using primer SRAP-3. In addition, one band of $216 \mathrm{bp}$ was revealed in all treatments of the Sids 13 cultivar and was absent in all treatments of Gimeza 12 , using primer SRAP-4. One band with a molecular size of $500 \mathrm{bp}$ disappeared from the $\mathrm{WW}+$ nano- $\mathrm{ZnO}$ and WS + nano-ZnO treatments of the Gimeza 12 cultivar, WW, $\mathrm{WS}+$ nano- $\mathrm{TiO}_{2}$, and $\mathrm{WS}+$ nano- $\mathrm{ZnO}$ in the Sids 13 cultivar, while appeared with the remaining treatments, using primer SRAP-5. Also, one amplified fragment of $380 \mathrm{bp}$ was absent in the Sids 13 cultivar treated with WW and WS + nano- $\mathrm{TiO}_{2}$, but appeared with the other treatments. In addition, one band with a molecular size of $277 \mathrm{bp}$ disappeared in $\mathrm{WW}, \mathrm{WW}+$ nano$\mathrm{TiO}_{2}$, and $\mathrm{WW}+$ nano-ZnO of the Gimeza 12 cultivar and $\mathrm{WW}, \mathrm{WW}+$ nano- $\mathrm{TiO}_{2}$, and $\mathrm{WS}+$ nano- $-\mathrm{TiO}_{2}$ in the Sids13 cultivar. It was found in all the other treatments, using primer SRAP-5. It is noted that one fragment of $512 \mathrm{bp}$ was exhibited in the Sids 13 cultivar treated at $\mathrm{WW}+$ nano- $\mathrm{TiO}_{2}$, $\mathrm{WW}+$ nano- $\mathrm{ZnO}$, and $\mathrm{WS}$ and was absent in the rest of the treatments, using primer SRAP-6.

Results show that drought WS and $10 \mathrm{mg} \cdot \mathrm{L}^{-1}$ of treatments for $\mathrm{TiO}_{2}$ or $\mathrm{ZnO}$ NPs have little effect on DNA and are illustrated with the appearance or absence of the bands. Moreover, the Sids 13 cultivar was more affected by treatments than the Gimeza 12 cultivar. The study showed that the low concentration of nanoparticles had not caused DNA damage. In contrast, the high concentration of nanoparticles induced DNA damage. Our results are closely in accordance with those recorded by Al Quraidi 


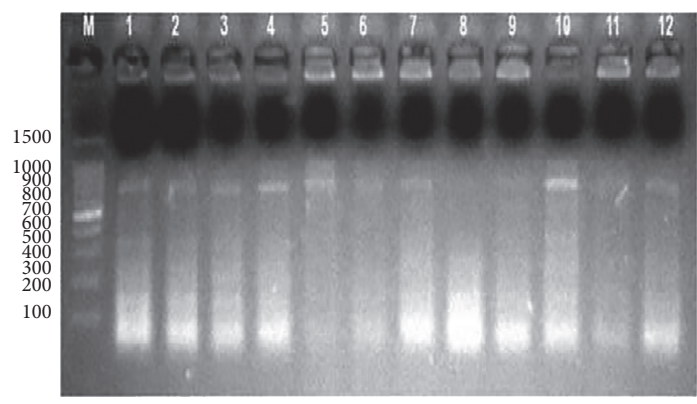

SRAP-1

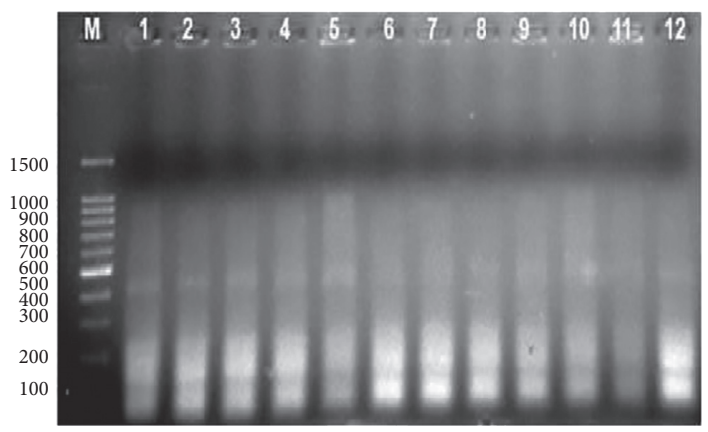

SRAP-3

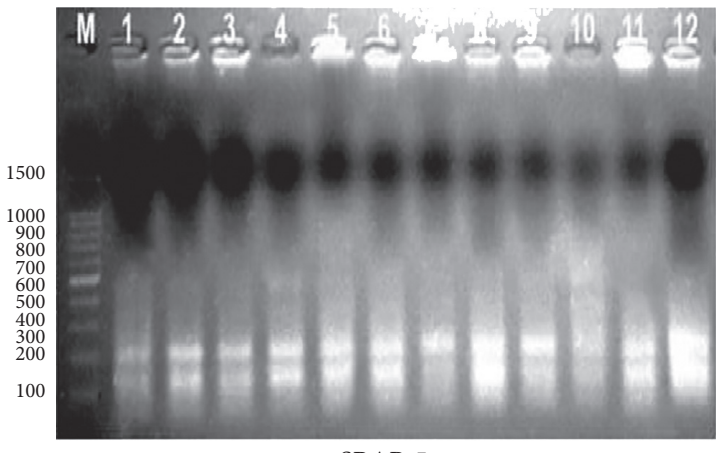

SRAP-5

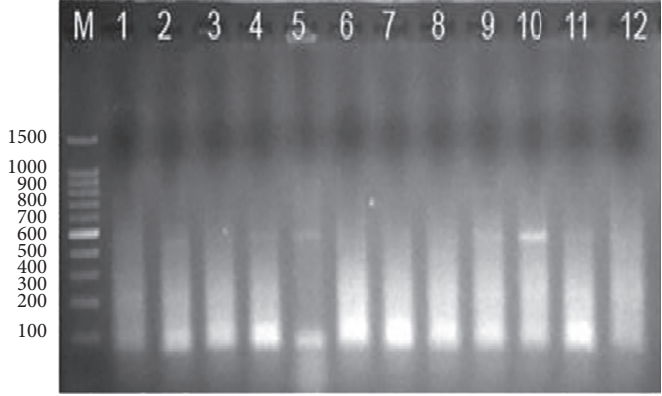

SRAP-2

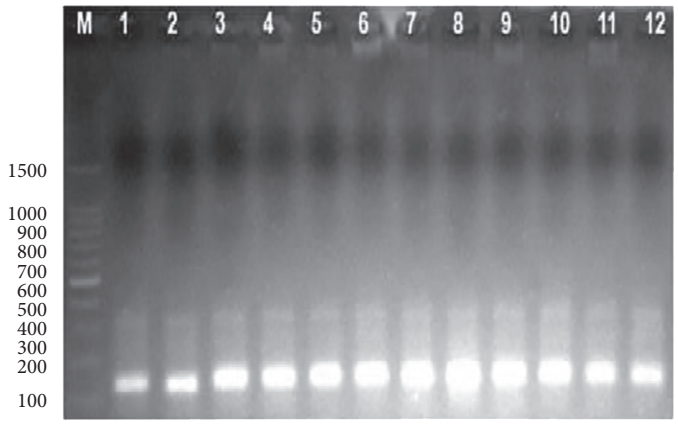

SRAP-4

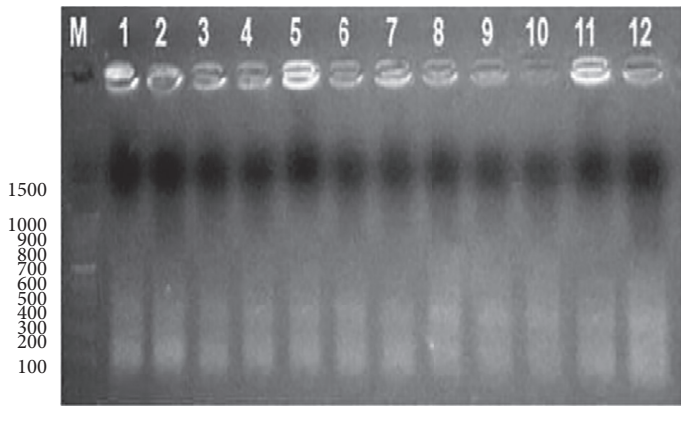

SRAP-6

FIGURE 7: SRAP-PCR profiles using six primers of two wheat cultivars treated and untreated with nanoparticles at 75 days from sowing. Lane M: 100 bp DNA Ladder; Gimeza 12 (lane 1: WW (control); lane 2: WW + nano- $\mathrm{TiO}_{2}$; lane 3: WW + nano-ZnO; lane 4: WS; lane 5: $\mathrm{WS}+$ nano- $\mathrm{TiO}_{2}$; and lane 6: WS + nano- $\mathrm{ZnO}$ ); Sids 13 (lane 7: WW (control); lane 8: WW + nano- $\mathrm{TiO}_{2}$; lane 9: WW + nano-ZnO; lane 10: WS; lane 11: WS + nano- $-\mathrm{TiO}_{2}$; and lane 12: WS + nano- $\left.\mathrm{ZnO}\right)$.

et al. [69], who obtained cytotoxic effects of cucumber plants (Cucumber sativus) treated with $\left(50 \mathrm{mg} \cdot \mathrm{L}^{-1}\right.$, $100 \mathrm{mg} \cdot \mathrm{L}^{-1}$, and $150 \mathrm{mg} \cdot \mathrm{L}^{-1}$ ) CuNPs. Moreno-Olivas et al. [70] used RAPD to evaluate the genotoxicity in Cucurbita pepo treated with $\mathrm{TiO}_{2}$ which established DNA changes in treated versus control conditions. Also, Mattiello et al. [71] assessed the genotoxicity in Hordeum vulgare L. treated with cerium oxide $\left(\mathrm{CeO}_{2}\right)$ and titanium oxide $\left(\mathrm{TiO}_{2}\right)$ using RAPD profiles. López-Moreno et al. [72] used a RAPD assay to find DNA damage and mutations that occurred due to nanoparticles. The appearance of four new bands at $2000 \mathrm{mg} \cdot \mathrm{L}^{-1}$ and three new bands at $4000 \mathrm{mg} \cdot \mathrm{L}^{-1}$ treatment of $\mathrm{CeO}_{2} \mathrm{NPs}$ were recorded. Andersen et al. [73] reported that stimulation or inhibition influences on germination and early growth were detected in response to the nanoparticles, based on the species of plant. Gene expression was measured during germination and early seedling proliferation. In A. thaliana, $\mathrm{TiO}_{2}$ and $\mathrm{CeO}_{2} \mathrm{NPs}$ induced several genomic responses as regulation in genes responsible for oxidative stress, which was responsible for early growth and development.

\section{Conclusion}

Water stress produced an opposing influence on plants through decreased growth, development, photosynthetic efficiency, and water status. The deleterious influences encouraged through a drought can be ameliorated via the application of nano- $\mathrm{TiO}_{2}$ and $\mathrm{ZnO}$ in wheat plants. They enhanced growth, grain yield, and crop water productivity in both wheat cultivars. Also, nanoparticles raised photosynthetic pigments and osmoprotectant content, and some protein bands were improved. It was observed that 
nano- $\mathrm{TiO}_{2}$ and $\mathrm{ZnO}(10 \mathrm{mg} / \mathrm{L})$ were the most efficient in wheat cultivars exposed to water deficits. The results showed that the Gimeza 12 cultivar was more tolerant to drought and had the highest grain yield than the Sids 13 cultivar.

\section{Data Availability}

The original contributions presented in the study are included within the article, and further inquiries can be directed to the corresponding author.

\section{Conflicts of Interest}

The authors declare that they have no conflicts of interest.

\section{Authors' Contributions}

Prof. Hala M.S. El-Bassiouny and Maha M.S. Abdallah involved in the planning of the work, were responsible for all the physiological and biochemical analysis, and wrote the manuscript. Associate Prof. Heba A. Mahfouze and Magda A. M. El-Enany involved in the planning of the work, were responsible for the biochemical and molecular analysis, and wrote the manuscript. Prof. Bakry A. Bakry involved in the planning of the work, farming of the plants and follow-up, taking samples, and statistical data analysis and wrote the manuscript. All authors read and approved the final manuscript.

\section{Acknowledgments}

The authors are thankful to the National Research Centre for the provision of laboratory facilities to carry out this research.

\section{References}

[1] S. Fahad, A. A. Bajwa, U. Nazir et al., "Crop production under drought and heat stress: plant responses and management options," Frontiers of Plant Science, vol. 29, no. 8, 2017.

[2] M. H. Soliman, A. A. M. Alayafi, A. A. El Kelish, and A. M. Abu-Elsaoud, "Acetylsalicylic acid enhance tolerance of Phaseolus vulgaris L. to chilling stress, improving photosynthesis, antioxidants and expression of cold stress responsive genes," Botanical Studies, vol. 59, no. 6, pp. 6-17, 2018.

[3] P. Jaspers and J. Kangasjärvi, "Reactive oxygen species in abiotic stress signaling," Physiologia Plantarum, vol. 138, no. 4, pp. 405-413, 2010.

[4] M. B. Bisbis, N. Gruda, and M. Blanke, "Potential impacts of climate change on vegetable production and product quality-a review," Journal of Cleaner Production, vol. 170, pp. 16021620, 2018.

[5] P. Gupta and B. De, "Metabolomics analysis of rice responses to salinity stress revealed elevation of serotonin, and gentisic acid levels in leaves of tolerant varieties," Plant Signaling \& Behavior, vol. 12, Article ID e1335845, 2017.

[6] C. Ma, S. Chhikara, B. Xing, C. Musante, J. C. White, and O. P. Dhankher, "Physiological and molecular response of Arabidopsis thaliana (L.) to nanoparticle cerium and indium oxide exposure," ACS Sustainable Chemistry \& Engineering, vol. 1, no. 7, pp. 768-778, 2013.

[7] S. Schiavo, M. Oliviero, M. Miglietta, G. Rametta, and S. Manzo, "Genotoxic and cytotoxic effects of $\mathrm{ZnO}$ nanoparticles for Dunaliella tertiolecta and comparison with $\mathrm{SiO}_{2}$ and $\mathrm{TiO}_{2}$ effects at population growth inhibition levels," The Science of the Total Environment, vol. 550, pp. 619-627, 2016.

[8] F. Hong, F. Yang, Q. Gao et al., "Effect of nano-anataseTiO on spectral characterization of photosystem II particles from spinach," Chemical Research in Chinese Universities, vol. 21, no. 2, pp. 196-200, 2005.

[9] L. Zheng, F. Hong, S. Lu, and C. Liu, "Effect of nano- $\mathrm{TiO}_{2}$ on strength of naturally aged seeds and growth of spinach," Biological Trace Element Research, vol. 104, no. 1, pp. 83-92, 2005.

[10] P. Moaveni, A. Talebi, H. A. Farahani, and K. Maroufi, "Study of nano particles $\mathrm{TiO}_{2}$ spraying on some yield components in barley (hordem vulgare L.)," in Proceedings of the International Conference on Environmental and Agriculture Engineering IPCBEE, pp. 115-119, Chengdu, China, July 2011.

[11] F. Yang, F. Hong, W. You et al., "Influences of nano-anatase $\mathrm{TiO}_{2}$ on the nitrogen metabolism of growing spinach," Biological Trace Element Research, vol. 110, no. 2, pp. 179-190, 2006.

[12] M. A. Albrecht, C. W. Evans, and C. L. Raston, "Green chemistry and the health implications of nanoparticles," Green Chemistry, vol. 8, no. 5, pp. 417-432, 2006.

[13] H. Alharby, E. Metwali, M. Fuller, and A. Aldhebiani, "Impact of application of zinc oxide nanoparticles on callus induction, plant regeneration, element content and antioxidant enzyme activity in tomato (Solanum lycopersicum Mill.) under salt stress," Archives of Biological Sciences, vol. 68, no. 4, pp. 723-735, 2016.

[14] M. V. Khodakovskaya, K. de Silva, A. S. Biris, E. Dervishi, and H. Villagarcia, "Carbon nanotubes induce growth enhancement of tobacco cells," ACS Nano, vol. 6, no. 3, pp. 2128-2135, 2012.

[15] H. Agarwal, S. Rajeshkumar, and S. A. Rajesh Kumar, "A review on green synthesis of zinc oxide nanoparticles-an ecofriendly approach," Resource-Efficient Technologies, vol. 3, no. 4, pp. 406-413, 2017.

[16] A. Singh, N. B. Singh, I. Hussain, H. Singh, V. Yadav, and S. C. Singh, "Green synthesis of nano zinc oxide and evaluation of its impact on germination and metabolic activity of Solanum lycopersicum," Journal of Biotechnology, vol. 233, pp. 84-94, 2016.

[17] H. Sturikova, O. Krystofova, D. Huska, and V. Adam, "Zinc, zinc nanoparticles and plants," Journal of Hazardous Materials, vol. 349, pp. 101-110, 2018.

[18] Y. Hao, P. Fang, C. Ma et al., "Engineered nanomaterials inhibit Podosphaera pannosa infection on rose leaves by regulating phytohormones," Environmental Research, vol. 170, pp. 1-6, 2019.

[19] A. A. H. Abdel Latef, M. F. Abu Alhmad, and K. E. Abdelfattah, "The possible roles of priming with $\mathrm{ZnO}$ nanoparticles in mitigation of salinity stress in lupine (lupinus termis) plants," Journal of Plant Growth Regulation, vol. 36, no. 1, pp. 60-70, 2017.

[20] S. Cenkci, M. Yıldız, İ. H. Ciğerci, M. Konuk, and A. Bozdağ, "Toxic chemicals-induced genotoxicity detected by random amplified polymorphic DNA (RAPD) in bean (Phaseolus vulgaris L.) seedlings," Chemosphere, vol. 76, no. 7, pp. 900-906, 2009.

[21] F. Al-Qurainy, "Application of inter simple sequence repeat (ISSR marker) to detect genotoxic effect of heavy metals on 
Eruca sativa (L.)," African Journal of Biotechnology, vol. 9, pp. 467-474, 2010.

[22] O. Miller, D. Helman, T. Svoray, E. Morin, and D. J. Bonfil, "Explicit wheat production model adjusted for semi-arid environments," Field Crops Research, vol. 231, pp. 93-104, 2019.

[23] A. Hossain and J. T. da Silva, "Wheat and rice, the epicenter of food security in Bangladesh," Songklanakarin Journal of Science and Technology, vol. 35, pp. 261-274, 2013.

[24] H. O. Chapman and P. E. Pratt, Methods of Analysis for Soils, Plants and Water Division of Agriculture Sciences University California, California, CA, USA, 1978.

[25] A. B. Bakry, A. I. Waly, N. Hemdan, and M. F. El-karamany, "Effect of soil amendments and water requirements on flax yield, fertilizer use efficiency and water productivity under sandy soil condition," American-eurasian Journal of Agronomy, vol. 12, no. 3, pp. 71-82, 2019.

[26] R. G. Allen, M. E. Jensen, J. L. Wright, and R. D. Burman, "Operational estimates of reference evapotranspiration," Agronomy Journal, vol. 81, no. 4, pp. 650-662, 1989.

[27] J. Keller and D. Karmeli, Trickle Design, Rain Bird Sp. Man, Glendora, CA, USA, 1975.

[28] T. A. Howell, R. H. Cuence, and K. H. Solomon, "Crop yield response," in Management of Farm Irrigation Systems, G. J. Hoffman, T. A. Howell, and K. H. Solomon, Eds., p. 312, ASAE, St. Joseph, MI, USA, 1990.

[29] H. K. Lichtenthaler and C. Buschmann, "Chlorophylls and carotenoids: measurement and characterization by UV-VIS spectroscopy," in Current Protocols in Food Analytical Chemistry (CPFA), R. E. Wrolstad, T. E. Acree, H. An et al., Eds., pp. F4.3.1-F4.3.8, John Wiley \& Sons, New York, NY, USA, 2001.

[30] M.-P. Prud' Homme, B. Gonzalez, J.-P. Billard, and J. Boucaud, "Carbohydrate content, fructan and sucrose enzyme activities in roots, stubble and leaves of ryegrass (lolium perenne L.) as affected by source/sink modification after cutting," Journal of Plant Physiology, vol. 140, no. 3, pp. 282-291, 1992.

[31] E. W. Yemm and A. J. Willis, "The respiration of barley plants. IX. The metabolism of roots during assimilation of nitrogen," New Phytotol, vol. 55, pp. 229-234, 1954.

[32] L. S. Bates, R. P. Waldren, and L. D. Teare, "Rapid determination of free proline for water-stress studies," Plant and Soil, vol. 39, no. 1, pp. 205-207, 1973.

[33] E. W. Yemm, E. C. Cocking, and R. E. Ricketts, "The determination of amino-acids with ninhydrin," Analyst, vol. 80, no. 948, pp. 209-213, 1955.

[34] U. K. Laemmli, "Cleavage of structural proteins during the assembly of the head of bacteriophage T4," Nature, vol. 227, no. 5259 , pp. 680-685, 1970.

[35] F. W. Studier, "Analysis of bacteriophage T7 early RNAs and proteins on slab gels," Journal of Molecular Biology, vol. 79, no. 2, pp. 237-248, 1973.

[36] T. Borsch, K. W. Hilu, D. Quandt, V. Wilde, C. Neinhuis, and W. Barthlott, "Noncoding plastid trnT-trnF sequences reveal a well resolved phylogeny of basal angiosperms," Journal of Evolutionary Biology, vol. 16, no. 4, pp. 558-576, 2003.

[37] H. A. Mahfouze, K. H. A. El-Dougdoug, B. A. Othman, and M. A. M. Gomaa, "Molecular markers in potato cultivars treated with ribosome-inactivating proteins," Pest Technology, vol. 6, no. 1, pp. 70-74, 2012.

[38] R. G. D. Steel and J. H. Torrie, "Principles and procedures of statistics," A Biometrical Approach, McGraw-Hill Book Company, New York, NY, USA, 2nd edition, 1980.
[39] T. L. Setter, "Transport/harvest index: photosynthetic partitioning in stressed plants," Stress Responses in Plant: Adaptation and Accumulation Mechanism, pp. 17-36, Wiley-Liss, Inc., New York, NY, USA, 1990.

[40] A. Jaberzadeh, P. Moaveni, H. R. Tohidi Moghadam, and $\mathrm{H}$. Zahedi, "Influence of bulk and nanoparticles titanium foliar application on some agronomic traits, seed gluten and starch contents of wheat subjected to water deficit stress," Notulae Botanicae Horti Agrobotanici Cluj-Napoca, vol. 41, no. 1, pp. 201-207, 2013.

[41] R. Mittler, "ROS are good," Trends in Plant Science, vol. 22, no. 1, pp. 11-19, 2017.

[42] R. Raliya, P. Biswas, and J. C. Tarafdar, " $\mathrm{TiO}_{2}$ nanoparticle biosynthesis and its physiological effect on mung bean (Vigna radiata L.)," Biotechnology Reports, vol. 5, pp. 22-26, 2015.

[43] O. Owolade, D. Ogunleti, and M. O. Adenekan, "Effects of titanium dioxide on the diseases, development and yield of edible cowpea," Journal of Plant Protection Research, vol. 48, no. 3, pp. 329-336, 2008.

[44] M. A. Shallan, H. M. M. Hassan, A. A. M. Namich, and A. A. Ibrahim, "Biochemical and physiological effects of $\mathrm{TiO}_{2}$ and $\mathrm{SiO}_{2}$ nanoparticles on cotton plant under drought stress," Research Journal of Pharmaceutical, Biological and Chemical Sciences, vol. 7, no. 4, pp. 1540-1551, 2016.

[45] H. M. S. El-Bassiouny, A. B. Bakry, M. H. Taha, and A. S. M. Younis, "Alleviation of salt stress and improve crop productivity by using arbuscular mycorrhiza and $\mathrm{ZnO}-\mathrm{Nano}$ or bulk particles in wheat," Plant Arch, vol. 19, pp. 205-214, 2019.

[46] E. A. Ali and A. M. Mahmoud, "Effect of foliar spray by different salicylic acid and zinc concentrations on seed yield and yield components of mungbean in sandy soil," Asian Journal of Crop Science, vol. 5, no. 1, pp. 33-40, 2012.

[47] E. Ebrahimian and A. Bybordi, "Exogenous silicium and zinc increase antioxidant enzyme activity and alleviate salt stress in leaves of sunflower," Journal of Food Agriculture and Environment, vol. 9, pp. 422-427, 2011.

[48] V. Tavallali, M. Rahemi, S. Eshghi, B. Kholdebarin, and A. Ramezanian, "Zinc alleviates salt stress and increases antioxidant enzyme activity in the leaves of pistachio (Pistacia vera L. Badami) seedlings," Turkish Journal of Agriculture and Forestry, vol. 34, pp. 349-359, 2010.

[49] M. S. Sadak, M. A. M. El-Enany, B. A. Bakry, M. M. S. Abdallah, and H. M. S. El-Bassiouny, "Signal molecules improving growth, yield and biochemical aspects of wheat cultivars under water stress," Asian Journal of Plant Sciences, vol. 19, no. 1, pp. 35-53, 2020.

[50] E. K. Liu, X. R. Mei, C. R. Yan, D. Z. Gong, and Y. Q. Zhang, "Effects of water stress on photosynthetic characteristics, dry matter translocation and WUE in two winter wheat genotypes," Agricultural Water Management, vol. 167, pp. 75-85, 2016.

[51] J. Mashilo, A. O. Odindo, H. A. Shimelis, P. Musenge, S. Z. Tesfay, and L. S. Magwaza, "Drought tolerance of selected bottle gourd (Lagenaria siceraria (Molina) Standl.) landraces assessed by leaf gas exchange and photosynthetic efficiency," Plant Physiology and Biochemistry, vol. 120, pp. 75-87, 2017.

[52] D. W. Lawlor and G. Cornic, "Photosynthetic carbon assimilation and associated metabolism in relation to water deficits in higher plants," Plant, Cell and Environment, vol. 25, no. 2, pp. 275-294, 2002.

[53] M. M.-S. Abdallah, Z. A. Abdelgawad, and H. M. S. ElBassiouny, "Alleviation of the adverse effects of salinity stress using trehalose in two rice varieties," South African Journal of Botany, vol. 103, pp. 275-282, 2016. 
[54] Y. Ze, C. Liu, L. Wang, M. Hong, and F. Hong, "The regulation of $\mathrm{TiO}_{2}$ nanoparticles on the expression of light-harvesting complex II and photosynthesis of chloroplasts of Arabidopsis thaliana," Biological Trace Element Research, vol. 143, no. 2, pp. 1131-1141, 2011.

[55] L. Tumburu, C. P. Andersen, P. T. Rygiewicz, and J. R. Reichman, "Molecular and physiological responses to titanium dioxide and cerium oxide nanoparticles inArabidopsis," Environmental Toxicology \& Chemistry, vol. 36, no. 1, pp. 71-82, 2017.

[56] R. Raliya and J. C. Tarafdar, " $\mathrm{ZnO}$ nanoparticle biosynthesis and its effect on phosphorous-mobilizing enzyme secretion and gum contents in clusterbean (cyamopsis tetragonoloba L.)," Agricultural Research, vol. 2, no. 1, pp. 48-57, 2013.

[57] L. Sun, F. Song, J. Guo et al., "Nano-ZnO-induced drought tolerance is associated with melatonin synthesis and metabolism in maize," International Journal of Molecular Sciences, vol. 21, no. 3, Article ID 782, 2020.

[58] M. Abdalla, "Beneficial effects of diatomite on the growth, the biochemical contents and polymorphic DNA in Lupinus albus plants grown under water stress," Agriculture and Biology Journal of North America, vol. 2, no. 2, pp. 207-220, 2011.

[59] M. S. Khater, "Effect of titanium nanoparticles $\left(\mathrm{TiO}_{2}\right)$ on growth, yield and chemical constituents of coriander plants," Arab Journal of Nuclear Science and Applications, vol. 48, no. 4, pp. 187-194, 2015.

[60] H. Mohammadi, M. Esmailpour, and A. Gheranpaye, "Effects of $\mathrm{TiO}_{2}$ nanoparticles and water-deficit stress on morphophysiological characteristics of dragonhead (Dracocephalum moldavica L.) plants," Acta Agriculturae Slovenica, vol. 107, no. 2, pp. 385-396, 2016.

[61] A. A. H. Abdel latef, A. K. Srivastava, M. S. A. El-sadek, M. Kordrostami, and L.-S. P. Tran, "Titanium dioxide nanoparticles improve growth and enhance tolerance of broad bean plants under saline soil conditions," Land Degradation \& Development 1-9, Wiley Online Library (wileyonlinelibrary.com), Hoboken, NY, USA, 2017.

[62] S. S. Amira, A. E. f. Souad, and D. Essam, "Alleviation of salt stress on Moringa peregrina using foliar application of nanofertilizers," Journal of Horticulture and Forestry, vol. 7, no. 2, pp. 36-47, 2015.

[63] H. M. S. El-Bassiouny, M. M. S. Abdallah, M. A. M. El-Enany, and M. S. Sadak, "Nano-Zinc Oxide and Arbuscular mycorrhiza Effects on physiological and biochemical aspects of wheat cultivars under saline conditions," Pakistan Journal of Biological Sciences, vol. 23, no. 4, pp. 478-490, 2020.

[64] H. M. S. El-Bassiouny, A. A. Abd El-Monem, M. M. S. Abdallah, and K. M. Soliman, "Role of arbuscular mycorrhiza, $\alpha$-tocopherol and nicotinamide on the nitrogen containing compounds and adaptation of sunflower plant to water stress," Bioscience Research, vol. 15, no. 3, pp. 20682088, 2018.

[65] A. Hajra and N. K. Mondal, "Effects of $\mathrm{ZnO}$ and $\mathrm{TiO}_{2}$ nanoparticles on germination, biochemical and morphoanatomical attributes of Cicer arietinum L," Energy, Ecology and Environment, vol. 2, no. 4, pp. 277-288, 2017.

[66] S. Dubchak, A. Ogar, J. W. Mietelski, and K. Turnau, "Influence of silver and titanium nanoparticles on arbuscular mycorrhiza colonization and accumulation of radiocaesium in Helianthus annuus," Spanish Journal of Agricultural Research, vol. 8, no. S1, pp. 103-108, 2010.

[67] N. Priyanka and P. Venkatachalam, "Biofabricated zinc oxide nanoparticles coated with phycomolecules as novel micronutrient catalysts for stimulating plant growth of cotton,"
Advances in Natural Sciences: Nanoscience and Nanotechnology, vol. 7, no. 4, Article ID 45018, 2016.

[68] A. Mukherjee, S. Majumdar, A. D. Servin, L. Pagano, O. P. Dhankher, and J. C. White, "Carbon nanomaterials in agriculture: a critical review," Frontiers of Plant Science, vol. 7, 2016.

[69] A. O. Al Quraidi, K. A. Mosa, and K. Ramamoorthy, "Phytotoxic and genotoxic effects of copper nanoparticles in coriander (coriandrum sativum-apiaceae)," Plants, vol. 8, no. 19, pp. 1-12, 2019.

[70] F. Moreno-Olivas, V. U. Gant, K. L. Johnson, J. R. PeraltaVidea, and J. L. Gardea-Torresdey, "Random amplified polymorphic DNA reveals that $\mathrm{TiO}_{2}$ nanoparticles are genotoxic to Cucurbita pepo," Journal of Zhejiang UniversityScience, vol. 15, no. 8, pp. 618-623, 2014.

[71] A. Mattiello, A. Filippi, F. Pošćić et al., "Evidence of phytotoxicity and genotoxicity in Hordeum vulgare L. Exposed to $\mathrm{CeO}_{2}$ and $\mathrm{TiO}_{2}$ nanoparticles," Frontiers of Plant Science, vol. 6, pp. 1-13, 2015.

[72] M. López-Moreno, G. de la Rosa, J. Hernandez-Viezcas et al., "Evidence of the differential biotransformation and genotoxicity of $\mathrm{ZnO}$ and $\mathrm{CeO}_{2}$ nanoparticles on soybean (Glycine max) plants," Environmental Science and Technology, vol. 44, pp. 7315-7320, 2010.

[73] C. Andersen, G. King, M. Plocher et al., "Effect of $n \mathrm{TiO}_{2}$ and $\mathrm{nCeO}_{2}$ nanoparticles on gene expression, germination, and early development in plants," in Proceedings of the International Congress on Safety of Engineered Nanoparticles and Nanotechnologies, Helsinki, Finland, April 2015. 